\title{
The Impact of Ambivalent Perception of Bureaucratic Structure on Cyberloafing
}

\author{
Prakriti Soral \& Jithesh Arayankalam \\ Indian Institute of Management Kozhikode, \\ India \\ prakritisoral@gmail.com \\ jithesh.a@gmail.com
}

\section{Jatin Pandey}

Indian Institute of Management Indore, India

\section{Abstract}

Cyberloafing, defined as the use of the Internet for personal use at the workplace, is emerging as a serious concern for organizations as it disrupts the attainment of organizational objectives. A systematic literature review, conducted as a part of this research, of antecedents of cyberloafing behaviour show that research exploring the relationship between the perception of organizational structure and cyberloafing is at a nascent stage. Acknowledging the underexplored state of research in this area, we investigated this relationship through a quantitative study using a sample of 201 employees, and the containment theory as the base. Our study results indicate that an ambivalent perception of the bureaucratic structure has a differential impact on the cyberloafing activities through serial mediation of two important attitudes, namely organizational identification and work engagement. Theoretical and practical implications are also discussed.

Keywords: cyberloafing; enabling bureaucracy; coercive bureaucracy; organizational identification; work engagement

\section{Introduction}

The rapid penetration of smartphones and laptops has made the Internet an indispensable part of our personal as well as work life. Realizing its benefits, companies are building up their technology platforms to facilitate work at the workplace (Griffiths, 2012). Open Internet access with high-speed data delivery is provided to the employees to make better and faster real-time decisions (McAfee, Brynjolfsson, Davenport, Patil, \& Barton, 2012). However, open Internet access may act as a double-edged sword (Li, Sarathy, Zhang, \& Luo, 2014) and promote counterproductive behaviour at the workplace. One such instance is the use of the Internet for personal activities, generally termed as cyberloafing. Formally, cyberloafing is defined as the unauthorized personal use of the Internet at work (Blanchard \& Henle, 2008; Lim, 2002; Lim, $\&$ Teo, 2005). In an era where every minute is crucial for the organizations, spending the supposedly productive working hours for unproductive Internet activities for personal use by the employees has emerged as a major problem for the organizations. As per Shrivastava, Sharma, and Marimuthu (2016), 57 per cent of Indian workers agree that Internet activities make them delay their work, and another study found that $89 \%$ of the US employees agreed that they waste their time every day by engaging into nonwork-related Internet activities (Salary.com, 2014). Monetary losses to the companies are enormous, and it was estimated that they suffer a loss of US\$759 billion annually because of cyberloafing activities (Martin, Brock, 
Buckley, \& Ketchen, 2010). Due to its impact on the productivity of the employees and security concerns for the organizations, studies on identifying the causes of cyberloafing activities have emerged as an active area of inquiry among the information systems (IS) researchers.

Most of the research in the cyberloafing literature has focused mainly on attitudes, interpersonal behaviours, and organizational policies (Liberman, Seidman, Mckenna, \& Buffardi, 2011; Pindek, Krajcevska, \& Spector, 2018). However, studies on the impact of formalized rules on cyberloafing through varied policies have given mixed results. For example, according to Shepherd, Mejias, and Klein (2014), presence of Acceptable Use Policies (AUP) reduces cyberloafing. Similarly, Bretschneider \& Parker (2016) found that such policies lead to reduction in the use of social media for personal use. On the contrary, Ahmad and Jamaluddin (2010) showed that computer and Internet usage policies have minimal impact on cyberloafing, while Stephens \& Ford (2015) found that placing restrictive mobile and Internet policies backfired to the organization. Such contradictions in findings make it necessary to identify the underlying dynamics among the aforementioned relationships, and calls for a deeper investigation into the psychological manifestations of organizational control on employees. Accordingly, we propose to study formalized rules from a holistic viewpoint using the perception of bureaucratic structure to know its impact on cyberloafing behaviour.

According to Adler and Borys (1996), even when two organizations are strikingly similar in structure, the perception of employees about bureaucratic elements may be entirely different, which cause employees to behave differently. To study this phenomenon, they proposed two types of perceptions towards bureaucratic structure, which are classified as enabling bureaucracy, where employees perceive bureaucracy as rational and a facilitator of employees' work, and coercive bureaucracy, where they perceive it as rigid and strict. For example, as we know, employees require autonomy and participation in decision-making to feel motivated and satisfied, and to improve their performance (Karasek \& Theorell, 1990; Pandey, 2019). However, when employees encounter the bureaucratic mechanisms and perceive them to be inflexible, it prohibits plurality in decision-making and engages into centralized power (Heffron, 1989), leading to lower commitment among the employees (Hartline, Maxham, \& McKee, 2000). Such an environment that restricts the innovation and creativity of employees (Adler \& Borys, 1996; Macher, 1988) abets the development of a perception toward the organizational structure as coercive, leading employees to indulge in delinquent behaviour. Furthermore, according to Lawrence and Robinson (2007), when an employee perceives the organizational power (a form of enforcing bureaucratic structure) to be using the "discipline" mechanism composed of surveillance, normalization, and examination (Foucault, 1979), it leads to production deviance (which in the present context is cyberloafing).

Above studies show that regardless of the purpose or intent of the enactment of power in organizations, an employee can perceive it negatively if it is impacting his/her autonomy, identity, and justice. This perception of being restricted by the organization results in frustration, eventually leading employees to indulge in deviant behaviour (Lawrence \& Robinson, 2007). Therefore, these perceptions of practices and structures in the organization are essential frames that colour the attribution and subsequent formation of attitudes and behaviours (Nishii, Lepak, \& Schneider, 2008; van de Voorde \& Beijer, 2015). This difference in perception may be the reason for the contrasting results of many studies about bureaucracy and job outcomes. For example, while Rousseau (1978) in his study identified bureaucracy to have a positive relationship with job satisfaction, Arches (1991) found that bureaucracy leads 
to job dissatisfaction. This incoherence in findings can be attributed to the negation of perceptual variables in these studies. Carrying forward this stream of research, our study focuses on enabling and coercive perceptions of bureaucracy.

Although the number of studies on the phenomenon of cyberloafing is on the rise, there is an apparent neglect as far as the effect of perception of organizational structure on cyberloafing activities is concerned (Sheikh, Atashgah, \& Adibzadegan, 2015). As the vestiges of Weber's bureaucracy can still be found in organizational structures across the world, cyberloafing tends to be affected by the perception of organizational structure. Through this research, we seek to answer how ambivalent perceptions about formalized rules and procedures, administrative hierarchy, and centralized decision-making affect nonwork-related Internet activities at work. Specifically, in this study, we investigate how perceptions of employees pertaining to enabling bureaucracy and coercive bureaucracy affect their cyberloafing activities. In addition, we believe that the perception of bureaucracy will manifest through job and organizational attitudes to impact cyberloafing behaviour. As several studies have empirically proved that perception leads to attitudes, which further lead to behaviour (Alfes, Truss, Soane, Rees, \& Gatenby, 2013; Kehoe \& Wright, 2010), we use work engagement and organizational identification as two attitudes to mediate this relation. Based on the aforementioned arguments, the research question we seek to answer through this study is as follows:

$R Q$ : How the perception of bureaucracy as enabling or coercive, along with organizational identification and work engagement, influence cyberloafing behaviour of an employee?

The present study draws from the Containment Theory (Reckless, 1961), which focuses on the effect of internal and external systems on deviant behaviour, to understand the impact of perception of bureaucratic structures on cyberloafing activities. As per the theory, the push and pull factors trigger the deviant behaviour by an individual, whereas inner and outer containments act as preventive mechanisms toward controlling the deviant activity. Drawing from this theory, we have proposed that outer containment (i.e., enabling bureaucracy) when further facilitated by the inner containment (i.e., organization identification and work engagement) will prevent cyberloafing behaviour. We have collected primary data from 201 participants using established scales and tested our model using covariance-based structural equation modelling (SEM). The results confirmed the indirect relationship between perceptions of bureaucracy and cyberloafing through organizational identification and work engagement.

\section{Literature Review}

\subsection{Cyberloafing}

The term 'cyberloafing' is used to describe the voluntary act of an individual to indulge in nonwork-related Internet activities at the workplace (Blanchard \& Henle, 2008; Lim, 2002). There are different views about the impact of cyberloafing activities in an organization. While some researchers favour its conduct because of its ability to act as a stress reliever, and as a source of learning and skill development (Belanger \& Van Slyke, 2002), others disapprove of these activities because of loss of productivity, security concerns, and reduction in concentration while working (Chen, Chen, \& Yang, 2008; Scheuermann \& Langford, 1997). Researchers are of the view that organizations should handle cyberloafing activities with care without affecting employees' productivity. When working on repetitive tasks, employees may 
feel bored and stressed (Pindek et al., 2018). In such situations, cyberloafing may help in relieving the stress by providing an avenue for a break and may help employees to re-focus on work again (Anandarajan \& Simmers, 2005). Through proper monitoring of cyberloafing activities, organizations can understand the underlying reasons for such behaviour and act upon it. Forcefully eliminating cyberloafing may bring about a feeling of alienation in employees as it may influence their job satisfaction level and may lead to the perception of being under coercive control (Case \& Young, 2002). So, it is essential to have a balance between cyberloafing activities and work productivity by understanding the concerns of the employees (Zoghbi Manrique de Lara, Tacoronte, \& Ding, 2006). These contrasting viewpoints underscore the necessity of a more nuanced understanding of the causes of cyberloafing.

Cyberloafing behaviours are caused by individual as well as related organizational factors. As per Van Doorn (2011), cyberloafing is predominantly a deviant behaviour because it is conducted voluntarily against the organizational norms, which occur when employees try to avoid work-related activities. He also found addiction behaviour and recovery behaviour as the causes of cyberloafing. In recovery behaviour, employees engage in nonwork-related activity to recover from work-related activities. Such behaviours arise while recovering from job burnout (Aghaz \& Sheikh, 2016), job stress (Koay, Soh, \& Chew, 2017b), and workplace boredom (Pindek et al., 2018). Another behaviour is addiction behaviour, that is when employees engage in cyberloafing as a habit, and it may get amplified in the case of boredom or dissatisfaction (Larose, Kim, \& Peng, 2011; Yellowlees \& Marks, 2007). As per the deviance model proposed by Robinson and Bennett (1995), cyberloafing falls under production deviance quadrant, which affects the organization, though in a minor way. Few of the other individual-level factors like lack of self-control and propensity to procrastinate work-related tasks are also two prominent causes of cyberloafing (Kim \& Byrne, 2011). Cyberloafing also occurs due to organizational factors such as ease of Internet access, due to which the demarcation between work and nonwork activities becomes unclear. They may take advantage of this high accessibility to the Internet by indulging in non-work-related activities just by sitting at their desk (Lim \& Teo, 2005). Ease of access, hidden identity, and ease to neutralize (Lim \& Teo, 2005) provoke such activities. Other external causes are lack of organizational justice (Chang \& Smithikrai, 2010), weak ethical leadership, feeble corporate culture (Zoghbi-Manrique-de-Lara \& Viera-Armas, 2017), loosely defined Internet policies; and perceived cyberloafing activities of one's co-workers (Liberman et al., 2011).

Although there is a debate regarding the acceptance of indulgence in cyberloafing activities, there is a consensus on what are the serious and nonserious cyberloafing activities. These activities that are classified as serious deviants are online shopping, playing games, visiting adult-oriented websites, and downloading nonwork-related material (Hadlington \& Parsons, 2017; Lim \& Teo, 2005). These activities have severe repercussions on organizational productivity. Other activities, such as checking the news and sending and receiving nonworkrelated emails, are considered to be minor activities (Blanchard \& Henle, 2008). Employees engaged in minor cyberloafing are generally unaware that they are engaging in deviant behaviours and continue to indulge in these activities because of vicarious influence from peers (Blanchard \& Henle, 2008).

Cyberloafing studies have gained prominence in recent years, and some of the studies are related to identifying the extent of prevalence of cyberloafing (Liberman et al., 2011), the impact of cyberloafing on emotions (Lim \& Chen, 2012), seriousness and justification of 
engaging in such activities (Lim \& Teo, 2005), and preventive mechanisms like sanctions (Khansa, Kuem, Siponen, \& Kim, 2017a; Ugrin \& Michael Pearson, 2013). Other constructs studied were job attitude, job burnout (Aghaz \& Sheikh, 2016), employee's emotions and perceptions (Lim \& Chen, 2012), job stress (Koay et al., 2017b), national culture (Ugrin, Pearson, \& Nickle, 2018), organizational stressors (Henle \& Blanchard, 2008; Pindek et al., 2018), organizational norms, and personality (Blanchard \& Henle, 2008). In order to provide a consolidated list of the causes of cyberloafing, we conducted a systematic literature review of the cyberloafing literature.

A systematic literature review helps in identifying data points that provide a consolidated idea of the existing literature and inform new concepts using structured steps of analysis. Papers were shortlisted in the following manner:

As our study is a multidisciplinary and includes literature from various disciplines such as criminology, psychology, and organizational studies, among others we selected Scopus, EBSCOhost, ScienceDirect, and Proquest as they are most extensive and commonly used multidisciplinary databases (Hebrew University, 2019). Guided by the objective of identifying the antecedents of cyberloafing behaviour, each of the above-listed databases was searched employing two keywords, namely, "cyberloafing" OR "cyberslacking," as an abstract search. Our search criteria was restricted only to the peer-reviewed articles published in English and "journal articles" as the document type. Further, we restricted the year of publication and shortlisted papers published in and after the year 2000. These elaborate search criteria helped us populate a list of 227 articles. In order to select the articles published in top category journals, we took articles published in $\mathrm{A}^{*}, \mathrm{~A}$ and $\mathrm{B}$ categories in the ABDC, and their equivalents in $\mathrm{ABS}$ list. After going through the abstract and subsequently the full text of each article, a total of 30 relevant articles were finalized.

Each of the authors independently reviewed the 30 identified papers. We went through the studies to identify the variables that were studied and empirically proved as the antecedents of cyberloafing behaviour. Each author independently scanned through the papers, listing down every antecedent mentioned therein. The articles were consolidated in Annexure I, highlighting the empirically proved antecedents, theories used, sample characteristics, methodologies used, and context of the studies. After pooling all the data, as well as critically reviewing it, we identified the organizing principle as type of variable. We developed nine categories based on the type of the variable and classified each antecedent under the appropriate category. Inferring from Annexure I, Annexure II provides a list of all the antecedents classified as per their respective variable type. The classification was initially done based on the authors understanding of the variables and later was cross-verified from the papers in which these antecedents were used. Majority of the antecedents studied in the cyberloafing literature were found to be based on perceptions, attitudes, and behaviour. From the given analysis, it is apparent that studies on the perceptions of organizational structure, and attitudes such as organizational identification and work engagement, as antecedents of cyberloafing, are not yet developed.

\subsection{Bureaucracy}

Since its conceptualization by Weber, several researchers have given various interpretations of bureaucracy as per changing times. Although bureaucratic structures have prevailed since ancient days (Schott, 2000), the concept was formalized by Weber in the year 1955 in his seminal work Wirtschaft und Gesellschaft. As per Zey-Ferrell, Weaver, and Ferrell's (1979) 
interpretation, bureaucracy is the "maximization of organizational efficiency as a consequence of legitimate, rationally-based authority. Weber had little regard for practices of favouritism based on status (especially family connections) and the hiring of personal friends and saw bureaucratic organizations as correcting such practices" (p. 48). The bureaucratic form is considered as an ideal type, and it functions on a rational-legal authority (Jelinek \& Ahearne, 2006; Johnson, Wood, Brewster, \& Brookes, 2009). A structure celebrated by many due to its ability to improve the efficiency of operations (Adler \& Borys, 1996), bureaucracy also gets opposed by many due to its coercive tendency to command and control, limit to the creative inputs, and excessively standardize jobs (Von Mises, 1944). Although there was a reduction over the years in the prevalence of bureaucratic structure in organizations, due to the risk of losing out the operational benefits of bureaucracy, there is a resurgence in the adoption of bureaucratic forms (Alvesson \& Thompson, 2004). This is especially true in developing countries, where government organizations still depend on bureaucratic structures to handle developmental challenges (Utaybi, 1992).

Richard Hall (1963) gave some of the most accurate features of bureaucracy, namely, the hierarchy of authority, division of labour, rule-based, formalized, impersonal, and technical qualification. These features represent the bureaucratic structure but yield varied consequences. Adler and Borys (1996) defined formalization as the extent to which rules, regulations, and procedures have been written down to impact on organizational functioning. Centralization is defined as the decision-making power residing in the hands of a few people at the top of the organizational pyramid (Hall, 1963). Both formalization and centralization explain the significant features of bureaucracy (Adler \& Borys, 1996). Although such features of the organizational structure were prominently studied (Adler, 2012), perceptions of employees about these features have not been much investigated. As per Adler (2012), to understand the success or failure of an organizational setup, such perceptions need to be studied.

Lewin (1936) suggested that people respond and direct their behaviour by their perception of reality and not reality itself. Such perceived realities are crucial and need to be studied. Adler (2012) also highlights the importance of the perception of employees toward the bureaucratic organizational structure and concludes that employees perceive bureaucracy as coercive as well as enabling. Enabling bureaucracy is perceived as facilitating employees' motivation and performance, whereas coercive bureaucracy is perceived to engender alienation and deviant behaviours (Adler \& Borys, 1996). According to Adler (2012), the concept of bureaucracy explained by Weber (1958) and Gouldner (1954) does not take into account this ambivalence toward bureaucracy. Even though the bureaucracy is implemented and practised as an enabler or a mix of enabler and coercive forces, employees' perception may vary, and it may subsequently reflect upon their behaviour (Adler, 2012). There are several studies on the existence of bureaucratic form in organizations. However, little has been studied about how employees differentiate between enabling bureaucracy and coercive bureaucracy.

\subsection{Organizational Identification}

Organizational identification arises when an employee displays a strong sense of "perception of oneness with or belongingness to" the focal organization (Ashforth \& Mael, 1989, p. 34). The term has its roots in social identity theory, and it shares a similar idea of relating oneself with the values and goals of the outer being. Organizational identification occurs at both the cognitive and affective level. While the cognitive part explains the degree to which an 
individual feels they belong to the organization (Ashforth \& Mael, 1989), the affective component helps in developing a positive image of one's organization (Tajfel, 1982). Both the elements together affect the level of organizational identification.

Organizational identification is often confused with organizational commitment, and several authors have elaborately distinguished between them. In a seminal article by Ashforth and Mael (1989), the authors have argued the shortcomings in the measure of organizational commitment, and how organizational identification provides a better measure of the organizational attachment. Hatch and Schultz (2004) in their book critique the widely popular scale of organizational commitment given by Mowday, Steers, and Porter (1979), where one of the items uses the terms "goals" and "values" in a generalized way, and not specific to a particular organization. However, the organizational identification construct clearly mentions that people who are identified with their organization feel some psychic loss while leaving the organization (Levinson, 1970). Such difficulty is not felt by people who are committed because the person may transfer this commitment to the other organization, which proves to be more convenient for him/her. This brings out the idea that "identified" people are more attached to the specific organization in which they work as compared to the employees who are just "committed" to the organization.

\subsection{Work Engagement}

Schaufeli and Bakker (2004, p. 295) define work engagement as a "positive, fulfilling, workrelated state of mind that is characterized by vigour, dedication, and absorption." It is a longterm dedication that arises out of an affective and cognitive state (Schaufeli, Salanova, Gonzalez-Romá, \& Bakker, 2002). Schaufeli et al. (2002) gave three categorizations of work engagement, which are (a) vigour, (b) dedication, and (c) absorption. While vigour explains the high level of energy an employee experiences while working on the job that fosters a strong sense of willingness to invest significant efforts in the job, dedication refers to being involved in work with full enthusiasm, getting inspired by the job, and taking pride in working while understanding its significance. Moreover, absorption is based on the degree of captivation by the work so much so that an employee loses the sense of time and it becomes difficult to be detached from the job (Maslach, Schaufeli, \& Leiter, 2001). The strong psychological bond between the employee and organization may motivate the employee to direct his/her efforts toward the work performance (Dutton, Dukerich, \& Harquail, 1994). Constructs such as job commitment, job involvement, and job satisfaction were frequently discussed in the literature as being similar but distinct to work engagement. For example, Nan Wyk, Boshoff, and Cilliers (2003) showed that job involvement is similar to the involvement aspect of work engagement; however, the dimensions of energy and effectiveness are not explained by job involvement. Work engagement is said to be a mega construct that incorporates work or job commitment into it, becoming a larger multidimensional aggregate factor (Dalal, Brummel, Wee, \& Thomas, 2008; Macey \& Schneider, 2008; Newman \& Harrison, 2008). Further, according to Rich, Lepine and Crawford (2010), it provides a "comprehensive explanation for job performance than do concepts that depict the self, more narrowly" (p. 618). From this explanation, it is clear that work engagement is a broader construct, and is unique due to its energy dimension, i.e., employees high on work engagement tend to be more resilient, optimistic and have active coping style (Christian \& Slaughter, 2007). 


\section{Theory and Hypotheses}

To answer our research question, we draw on the containment theory (Reckless, 1961) from criminology discipline. Although the theory is acknowledged as the best general theory to explain the vast array of delinquent behaviours (Reckless, 1967), it is still not much used in organizational studies. The key strength of the theory lies in its ability to explain both the situations when a person behaves in a delinquent manner, and when she/he does not. The theory argues how external social factors and inner self factors helps in controlling the delinquent behaviour of a person. To elaborate, as per the theory, there are two delinquency inducing factors (i.e., push and pull factors) and two delinquency containing factors (i.e., inner and outer containments). The pull factors include the environmental factors that 'pull' individuals towards delinquent behaviour, whereas, push factors include the psychological aspects such as perceptions and attitudes of a person that 'pushes' him/her towards delinquency. While inner containment is the "ability of the individual to follow the norms" (Reckless, 1967, p.475), outer containment represents the "capability of society, groups, organizations and communities to hold the behaviour of individuals in the bounds of accepted norms, rules." (Reckless, 1967, p. 475)

We have re-conceptualized this theory in the organizational context to study the relationships between coercive and enabling bureaucracies, organizational identification, work engagement, and cyberloafing. As discussed before, the outer containment describes the capacity of the factors external to the individual to hold him/her within the acceptable norms and expectations. It consists of three factors that help in preventing delinquent behaviours: (a) reasonable limits and expectations, (b) meaningful roles and activities, and (c) supportive relationships or adequate supervision (Beebe \& Rao, 2005; Reckless, 1961). If the individual perceives these factors as favourable and conforming, they are less likely to engage in a delinquent activity (Dodder \& Long, 1980). Since, in the context of our study, the perception of enabling bureaucracy is also conceptualized in similar terms, that is, a person will perceive bureaucracy as enabling when the rules and standards set by the organization are perceived as facilitators to his/her work (Hess, 2006), we represent the outer containment as the perception of enabling bureaucracy.

However, these outer containments should be facilitated by the inner containments, which are represented by four components of self: (a) a favourable self-perception; (b) goal direction towards approved behavioural patterns; (c) frustration tolerance; and (d) retention of norms. These factors represent "self-imposed limits on one's conduct that are formed out of recognition and internalization of pro-social norms, as well as one's attachment to pro-social ideals" (Kennedy, 2015, p. 51). When employees identify themselves with the values, norms, rules, and customs of an organization, they are less likely to engage in deviant behaviour (Reckless, 1967) because they feel responsible for the work or to the organization. These containment factors help in creating a sense of belonging and identity with the organization (Reckless, 1967). As studied in the literature, employees with a high level of identification with the organization prioritize the welfare of the organization and showcase a more helpful behaviour towards it (Priesemuth, Schminke, Ambrose, \& Folger, 2014; Ashforth \& Mael, 1989). In contrast, when employees' identification with the organization is low, they will be less concerned about its success (Liu, Yang, Liu \& Zhu, 2018) and will engage in harmful behaviour. Similarly, studies have shown that employees with a high level of work engagement display less of deviant behaviour (Shantz, Alfes, Truss, \& Soane, 2013). 
Accordingly, a high level of engagement towards the work or identification with the organization acts as a strong inner containment, preventing delinquent behaviour. Consequently, we have conceptualized inner containment with organizational identification and work engagement variables.

To make these four inner containments more aligned to the organizational setting, we have conceptualized (1) self-concept, retention of norms, and goal orientation as organizational identification, and (2) frustration tolerance as work engagement, because of following reasons.

a) Self-perception is generally conceptualized as self-concept, that is, a person may behave in the way he/she may perceive himself/herself (Epitropaki, 2013). For example, a person perceiving himself or herself as honest and reliable will act accordingly. Selfperception or self-concept is a self-regulatory variable that directs a person toward having certain work-related attitudes, perceptions, and behavioural intentions (Epitropaki, 2013). So, the people who adopt the organization's missions and values in their self-concept tend to think and act in an organizationally consistent way (Efraty \& Wolfe, 1988). As a highly identified individual will embed the organizational membership in one's self-concept and will develop consistency with the organizational values (Van Dick, Ullrich, \& Tissington, 2006), we have conceptualized self-concept as per organizational identification.

b) As retention of norms means adherence, acceptance, legitimizing the rules, values, or customs of the institution (Reckless, 1967), people identifying with the organization adhere to the norms because they take pride in the organization and internalize the organization's goals and values (Cook \& Wall, 1980). Individuals identifying with the organization accept its norms, goals, and values, and integrate them into their belief system (Ashforth \& Mael, 1989; Pratt, 1998). Taken together, retention of norms is conceptualized using organizational identification construct.

c) The concept of goal direction indicates that when a person is having goal-oriented behaviour, he/she will conform to the rules existing in the society in order to achieve his/her goals. As identification with organization leads to congruence with the organization's goal (Dutton et al., 1994), it is also conceptualized with organizational identification.

d) Frustration tolerance explains the power of an individual to be focused even if the person is forced to divert from his/her course. Bakker and Demerouti (2008) and Ugwu and Onyishi (2017), in their studies, highlighted that in the presence of work engagement, an employee develops the power of tolerating the frustration. The three factors of work engagement, namely, vigour, dedication, and absorption, create a flowlike situation (Csikszentmihalyi, 1997), which helps the individuals to handle the frustration arising out of various reasons. Hence, frustration tolerance is conceptualized using work engagement.

Therefore, the presence and practice of these internal containments, along with outer containment factors, will prevent delinquent behaviour (Reckless \& Dinitz, 1968).

The delinquency inducing pull factor represents pulling a person away from the normal way of working (Reckless, 1961). An employee working in a bureaucratic setup develops a perception of coercive bureaucracy because he/she feels being detached from his/her normal way of working, i.e., having freedom at work and having the autonomy to take decisions. 
Working in such a rigid structure may lead to a feeling of aggression and frustration (Push factor). Such pushes and pulls together will produce delinquent behaviour unless they are counteracted by inner and outer containment (Akers, 1994). However, sometimes, the pressure of push and pulls are so strong that it is difficult for even the self (inner) or for the groups (outer) to contain it (Reckless, 1961). In our study, we represent the push and pull factors as the perception of coercive bureaucracy (Figure 1).

\section{OUTER CONTAINMENT}

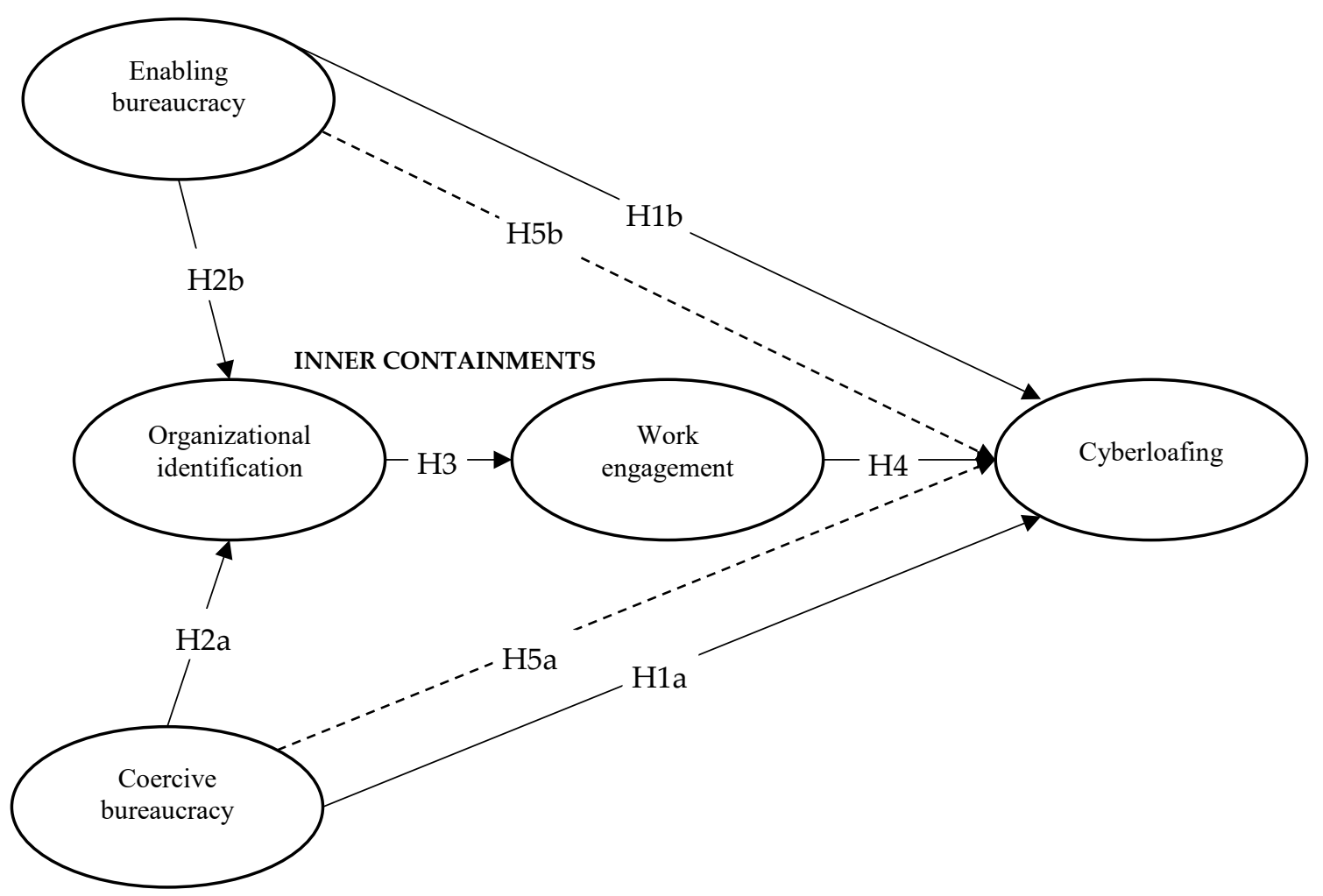

\section{PULL AND PUSH FACTORS}

\section{Figure 1. Structural model}

Although criminology theories such as general deterrence theory (GDT) have been used in the cyberloafing literature to explain how Internet usage policy at the workplace will lead to control of the cyberloafing behaviour, it addresses only the fear inducement as the controlling strategy (Jia, Jia, \& Karau, 2013). Similarly, Zoghbi Manrique de Lara et al. (2006), using the control theory, studied the impact of three coercive variables on cyberloafing. Using the containment theory, we are proposing that other noncoercive factors may also contribute in controlling deviant behaviours such as cyberloafing. Moreover, several studies have used the stress theories such as Conservation of Resources theory or Strain theory (Koay et al., 2017b), to explain the cyberloafing behaviour. While these studies only explained the external factors that cause the stress i.e., job stress and private demands, the containment theory provides a better explanation in understanding the cyberloafing behaviour due to the following two key reasons: (a) it helps in understanding both the deviant inducing behaviours and deviant containing behaviours; (b) both the inducing and containing factors can be studied from the 
perspective of inner self as well as external environment. These key reasons help us in understanding the differential impact of both the coercive and enabling perceptions of bureaucracy together on cyberloafing behaviour.

\subsection{Coercive Bureaucracy}

The pioneers of bureaucratic ideology such as Max Weber, Ernst Freund, and Fredrick Taylor had a positive notion toward bureaucracy due to its disciplined mechanism to predominantly satisfy the needs of the owners (Frug, 1984). Several authors agree with Weber's definition of bureaucracy as an "iron cage" that facilitates organizational performance but at the cost of employees. Left Weberaians translate Weber's writings as "domination" rather than authority and view bureaucracy as a mechanism to experience and maintain dominance over employees (Bendix, 1960). Even researchers from Marxists philosophy share a similar opinion of bureaucracy as a tool for exploitation (Clawson, 1980).

Similarly, in bureaucracy, the power to control and command acts as a mechanism to preserve managerial power. Procedures formed with the objective to enhance control over employees may lead to anger and affect their engagement (McGuigan, 2005). This human cost involved in the bureaucratic setup may lead to psychological and physical stress, which results in absenteeism and increases the propensity to leave. Several studies focusing upon the negative impact of formalization on employees highlighted the feeling of powerlessness, selfestrangement (Kakabadse, 1986), job dissatisfaction (Arches, 1991), and anomie and alienation (Bonjean \& Grimes, 1970).

Bennis (1969) consolidated the issues with bureaucratic structures into two parts. The first part talks about the impact of bureaucracy on individuals in making them dull and grey like an "organization man," provides no room for personality development, discourages informal organizations, and leads to groupthink and conformity. The second part talks about how excessive use of control and authority, and lack of conflict-resolution mechanisms between hierarchical levels can negatively affect the communication, which in turn increases trust deficit among employees and employers.

The implications of the perceptions of such coercive bureaucratic structures may lead to employees behaving in a deviant way. Workplace deviance has been much explored in previous eras in relation with situational factors like boredom (Spector et al., 2006), individual factors like attitude and personality (Richards \& Schat, 2011), and organizational factors like abusive supervision (Tepper, Duffy, \& Shaw, 2001). Previous studies encourage researchers to explore the concept of deviant behaviour further and to study the role of the perception of organizational structure (such as bureaucratic structures) on such behaviours (Zimmerman, 2001). Recently, a few papers have come up elaborating upon this relationship (Jelinek \& Ahearne, 2006; Marasi, Bennett, \& Budden, 2018). Greenberg (1977) argues against bureaucracy and establishes that there exists a direct causal link between bureaucracy and deviant behaviour. Companies implementing bureaucracy act as a hindrance and restrict the free flow of communication among the employees. Such restrictions may lead to a feeling of being trapped and in order to let out such emotions, employees may engage in organizational or personal deviance (Jelinek \& Ahearne, 2006). Marasi et al. (2018) analyse how the level of participation in decision-making and controlled working environment influence employees' engagement in deviant behaviour. Thus, there is a possibility that perception of organizational structure such as bureaucratic structures can influence cyberloafing, which is a modern manifestation of deviant behaviour. 
One of the most prominent causes of deviant behaviour is alienation. Seeman (1971) gave five antecedents to alienation such as powerlessness, meaningless, normlessness, isolation, and self-estrangement. All these five causes may very well flow from a bureaucratic structure. Lack of control, unable to relate one's work with the ultimate goal of the individual, just achieving the extrinsic goal rather than internal goals, and rules not giving proper direction to achieve personal goals-all stem from bureaucratic organizations and may prove fatal to the employee's motivation (Seeman, 1971).

As discussed earlier, the containment theory proposes that push and pull factors act as a reinforcing mechanism for deviant behaviour (Reckless, 1967). Given this, we propose that the perceived coercive bureaucracy will further trigger the cyberloafing activities by the employee:

\section{Hypothesis 1a: Coercive bureaucracy is positively associated with cyberloafing.}

\subsection{Enabling Bureaucracy}

Past studies have tried to bring forth and highlight the justification of a bureaucratic setup. A rigid hierarchy, as seen in a bureaucratic organization, may even facilitate the work by bringing in best practices and coordination through formalization (Hall, 1968). As per Hall (1968), this formalization brings standard rules and procedures, which create congruence and unity in direction. Nicholson and Goh (1983), in their study, argued that a formalized working setup would lead to a reduction in role conflict and role ambiguity. Other positive outcomes of formalization are job satisfaction (Snizek \& Bullard, 1983), reduced emotional exhaustion (Pines \& Maslach, 1978), encouragement for innovation (Damanpour, 1991), facilitation of job performance (Deming, 1986), and reduction in the feeling of alienation and stress (Jackson \& Schular, 1985). Montagna (1968), in his study, proposes that with the introduction of formalized rules and norms, employees develop the understanding about their goals and ways to achieve them, thus reducing the need for direct supervision. Such a scenario will lead to autonomy for the employees, thus shifting the negative connotation of the bureaucracy toward a positive one.

As per the concept of enabling bureaucracy, bureaucratic structures are seen as problem solvers, which help in attaining a higher level of efficiency (Adler \& Borys, 1996; Saparito \& Coombs, 2013). It facilitates flexibility, promotes creativity, and encourages innovation by transfer of technology. Another view as given by Hess (2006) toward enabling bureaucracy is its ability to set standards for the employees. These standards showcase the best way of performing the tasks, provide support for handling multiple jobs, and improve the capabilities of the workers (Hess, 2006). The difference between enabling and coercive bureaucracy is that the former focuses upon the development of rules and regulations to enhance performance, whereas the latter focuses upon controlling the employees. Here, the formalization of rules and procedures does not hinder the work; instead, it acts as flexible guidelines that contribute to problem-solving. Also, centralization gets a new dimension to it where the decision-making power is centralized to the employees, and so leaders maintain a high level of accountability with the subordinates and share mutual benefits unlike in coercive bureaucracy, where the focus is only toward the betterment of owners (Utaybi, 1992).

From this discussion, it can be seen that the perception of bureaucracy as enabling is favourable to the employees. Given these arguments, we posit that the perceived enabling bureaucracy (outer containment) will reduce cyberloafing behaviour: 
Hypothesis 1b: Enabling bureaucracy is negatively associated with cyberloafing.

One very crucial aspect of organizational identification is that in addition to the need for identifying with the working, it requires employee's full participation in the organization, which develops a sense of membership with the organisation. This may not be fruitful in the case of bureaucratic organizations. Implementing strict rules and regulations and taking away the autonomy may develop perceived barriers to the organizational hierarchy. Such excessive rules, regulations, and procedures may limit the ability of the employee to see beyond (Stuart, 1999). Perceiving such a treatment from the organization may restrict the identification between employee and organization. Based on this, we hypothesize the following:

Hypothesis 2a: Coercive bureaucracy is negatively associated with organizational identification.

Bringing in the concept of social identity theory, Ashforth and Mael (1989) explained how an employee's identity with the organization cultivate into dedication towards work performance. Organizational identification creates a strong sense of cognitive and affective bond that culminate in the relationship with the organizational goals. Depending on this psychological bond, engagement with goals, values, and activities may increase or decrease (Dutton et al., 1994). A study conducted by Brown (1969) concluded that perceived access to organizational hierarchy has a strong direct relationship with organizational identification. Moreover, support from supervisors in terms of work-related help, being concerned, and understanding toward employees will lead to the development of identity with the organization (Benkhoff, 1997; Yoon, Baker, and Ko, 1994). Hall, Schneider, and Nygren (1970) study shows a direct positive relationship between organizational identification and autonomy. Enabling formalization may help in building a congruence between the professional goals of an employee and organizational goals (Greene, 1978). It also makes the organization more meaningful to the individual by building up "institutional motivation" (Glaser, 1963). Li, Zhang, and Sarathy (2010), in their study, found out that individuals having a high level of organizational identification developed a self-norm toward appropriate use of computer resources provided to them. Such a component of trust between employees and organization develops a sense of duty to comply with the network policies (Adler, 2012). Based on this idea, we hypothesize that when an employee perceives his/her organization's bureaucratic structure as empowering, he/she may develop a sense of identity with the organization:

Hypothesis 2b: Enabling bureaucracy is positively associated with organizational identification.

The current literature explaining the relationship between work engagement and organizational identification is scant. According to Karanika-Murray, Duncan, Pontes, and Griffiths (2015), there is a positive relationship between organizational identification and work engagement, where engagement acted as a mediator between organizational identification and job satisfaction. So, to test the relationship further, we hypothesize that employees who strongly relate themselves to the organization may tend to engage in work as well:

Hypothesis 3: Organizational identification is positively associated with work engagement.

As explained by the concept of work engagement, employees who are engaged in their job work more efficiently and bring about better productivity (Bakker \& Demerouti, 2008). Similarly, if the employees are disengaged, they tend to indulge in deviant activities during working hours (Ketchen, Craighead, \& Buckley, 2008). When employees are engaged in their 
work, they will be less distracted and hence will not engage in deviant behaviour (Alias, Mohd Rasdi, Ismail, \& Abu Samah, 2013). Based on this, we hypothesize the following:

Hypothesis 4: Work engagement is negatively associated with cyberloafing.

Organizational control through rules and regulation also determines the level of engagement an employee will display. When there is a perception of bureaucracy as enabling rules are perceived to bring in best practices to the organization, and so, employees tend to work with more dedication. Moreover, this perception will create a positive attitude about the organizational functioning, which should lead employees identifying themselves with the organization. However, in a bureaucracy perceived as coercive, rules are seen as a coercive way of control, leading to disengagement with the work (Adler \& Borys, 1996).

Drawing from the containment theory (Reckless, 1967), we propose that if the outer containment, that is, bureaucracy perceived as enabling, gets reinforced by internal containments of work engagement and organization identification, all of it together will reduce the deviant behaviour. Moreover, the push and pull system, that is, bureaucracy perceived as coercive, will negatively affect the organizational identification and work engagement, leading to an increase in cyberloafing behaviour. Based on the above arguments, we hypothesize the following:

Hypothesis 5a: Perceived coercive bureaucracy has a positive indirect impact on cyberloafing through organizational identification and work engagement.

Hypothesis 5b: Perceived enabling bureaucracy has a negative indirect impact on cyberloafing through organizational identification and work engagement.

\section{Methods}

\subsection{Sample and Procedures}

The questionnaire was sent via email and hard copy to 733 employees. Organizations were identified in such a way that it included firms of all sizes. In total, 201 participants completed the survey. Since the sample constituted a great variety in occupation, organizational size, educational level of the employees, and the location of the organization, it was suitable for the study. The recommended sample size needs to be at least five times the number of parameters estimated (Bagozzi \& Yi, 1988). In the model, there are 25 parameters, and thus 201 is an adequate sample size for the analysis. The average age of the participants was 30.63 years, of which 70.4 per cent were male, and 28.2 per cent were females; 52.1 per cent of the respondents were graduates, and 45.5 per cent were postgraduates. The average tenure of the respondents was 5.18 years. Around 46.5 per cent of the respondents were unmarried. Nearly 40 per cent of the participants were from organizations that have more than 5,000 employees. Nearly 48 per cent of the respondents were professionals, whereas 32 per cent were in technical positions. Questionnaires were filled with the respondents' consent, and respondents' details were kept anonymous to make sure that honest responses were given.

Throughout the study, we followed the ethical standards recommended by the American Psychological Association (Smith, 2013). All work has been done according to those guidelines. With regard to what is known as the researcher bias, we took various steps to minimize it. Some of the major reasons for researcher bias are (1) poorly conceived questions leading respondents to answer in a forced way; and (2) question order bias, where the ordering of items affects the response (Driscoll, 2011) among others. In order to reduce the impact of these 
biases, in line with MacKenzie and Podsakoff (2012), and Wales, Patel, and Lumpkin (2013), we have used established scales for collecting the data. In addition, the data were collected anonymously, and we have also provided detailed statistical analysis in the form of tables throughout our article. In addition, to prevent bias due to the low self-efficacy of the respondents to give the correct answer, while collecting data, we emphasized to the respondents that only their personal experience or knowledge is required to fill the questionnaire.

\subsection{Measures}

The survey used a seven-point Likert scale unless otherwise stated. Each construct was measured using scales used in previous research. In order to check the internal validity of the constructs, a confirmatory factor analysis (CFA) was conducted. A few items were removed because of low factor loading. The constructs used in the study are explained below, and their definitions and measures are shown in Table 1.

\subsubsection{Perception of Bureaucracy}

Perception of bureaucracy was measured using a scale developed by Hoy and Sweetland (2001), which seeks to measure two crucial aspects of bureaucracy, namely, formalization and centralization. This scale further categorizes both these aspects as enabling and coercive. The scale consisted of 12 items, out of which six items were related to perception of bureaucracy as enabling and the remaining six items to perception of bureaucracy as coercive. Four items were removed because of low factor loading. An example item for perception of bureaucracy as coercive is "Administrative rules in this organization are used to punish employees." Similarly, an example item for perception of bureaucracy as enabling is "The administrators in this organizations use their authority to enable employees to their job."

\subsubsection{Cyberloafing}

Cyberloafing behaviour was measured using a scale designed by Lim and Teo (2005). This scale consists of 13 questions. In our study, considering the cultural sensitivity, we removed one question from the questionnaire, which is "Visit adult-oriented (sexually explicit) websites." Since we are considering only those activities which are considered as severe cyberloafing, we removed items that are considered nonserious as per Lim and Teo (2005) (e.g. "Receive nonwork-related email"). An example item of serious cyberloafing is "During office hours, how often do you use the Internet at work to access the following websites for personal reasons? Or Visit non-job-related websites." In the present study, major cyberloafing activities are considered to analyse the prevalence of cyberloafing among employees.

\subsubsection{Work Engagement}

Using a shortened scale of the Utrecht Work Engagement Scale (UWES), which consists of nine items, attitudes toward work were measured (Schaufeli \& Bakker, 2004). One item was removed because of low factor loading. An example item is "I am enthusiastic about my job."

\subsubsection{Organizational Identification}

This construct was measured using a five-item scale (Smidts, Pruyn, \& van Riel, 2001). An example item is "I feel proud to work for my company."

\subsubsection{Control Variables}

Education, personality, job type, number of working hours per week, size of the organization, income, and job position were added as control variables. Jia, Jia, and Karau (2013) found that 
personality factors such as conscientiousness, emotional stability, and extroversion have a significant relationship with cyberloafing. To capture the personality traits of the respondents, we used BFI-10 (Rammstedt \& John, 2007), a shorter version of the Big Five personality inventory. An example item is "I see myself as someone who is reserved." In addition, as per Case and Young (2002), the efficiency of Internet policies depends on the size of an organization. As Internet policy can affect cyberloafing, the organizational size was used as a control variable. Another control variable used is income, which has a significant effect on cyberloafing (Garrett \& Danziger, 2008). Aghaz and Sheikh (2016), in their study, showed that job burnout and cyberloafing have a positive relationship in the knowledge-intensive sector. As the sample in the present study was drawn from varied sectors, job type was used as a control variable. Further, the number of working hours was also controlled as we wanted to eliminate the possibility that more the amount of time spent at work, greater the possibility of cyberloafing.

\begin{tabular}{|c|c|c|}
\hline Construct & Definition & Measures \\
\hline Cyberloafing & $\begin{array}{l}\text { "Voluntary act of employees' using their companies' internet } \\
\text { access during office hours to surf non-job related Web sites for } \\
\text { personal purposes" (Lim, 2002, p. 677) }\end{array}$ & $\begin{array}{l}\text { Adopted serious } \\
\text { cyberloafing from the } \\
\text { 13-item scale used by } \\
\text { Lim \& Teo (2005) }\end{array}$ \\
\hline $\begin{array}{l}\text { Enabling } \\
\text { bureaucracy }\end{array}$ & $\begin{array}{l}\text { "Enabling bureaucracy is a structure that is formed by enabling } \\
\text { formalization and enabling centralization - the rules, } \\
\text { regulations, and procedures are helpful and lead to problem- } \\
\text { solving among members rather than rigid, coercive activities that } \\
\text { demand conformity." (Hoy \& Sweetland, 2001, p. 301). This is a } \\
\text { perceptual variable. }\end{array}$ & \multirow{2}{*}{$\begin{array}{l}\text { 12-item Scale } \\
\text { developed by Hoy \& } \\
\text { Sweetland (2001), out } \\
\text { of which six items are } \\
\text { related to enabling } \\
\text { bureaucracy, and the } \\
\text { remaining six items are } \\
\text { related to coercive } \\
\text { bureaucracy }\end{array}$} \\
\hline $\begin{array}{l}\text { Coercive } \\
\text { bureaucracy }\end{array}$ & $\begin{array}{l}\text { Coercive bureaucracy is "when formalization and centralization } \\
\text { coerce and hinder rather than help." (Hoy \& Sweetland, 2001, p. } \\
\text { 302). This is a perceptual variable. }\end{array}$ & \\
\hline $\begin{array}{l}\text { Organizational } \\
\text { identification }\end{array}$ & $\begin{array}{l}\text { Organizational identification arises when an employee displays } \\
\text { a strong sense of "perception of oneness with or belongingness } \\
\text { to" the focal organization (Ashforth \& Mael, 1989, p. 34) }\end{array}$ & $\begin{array}{l}\text { 5-item scale by Smidts, } \\
\text { Pruyn, \& van Riel } \\
\text { (2001) }\end{array}$ \\
\hline $\begin{array}{l}\text { Work } \\
\text { engagement }\end{array}$ & $\begin{array}{l}\text { Work engagement is defined as a "positive, fulfilling, work- } \\
\text { related state of mind that is characterized by vigor, dedication, } \\
\text { and absorption." (Schaufeli \& Bakker, 2004, p. 295) }\end{array}$ & $\begin{array}{l}\text { The 9-item shortened } \\
\text { scale of the Utrecht } \\
\text { Work Engagement } \\
\text { Scale (UWES) } \\
\text { (Schaufeli \& Bakker, } \\
\text { 2004) }\end{array}$ \\
\hline
\end{tabular}

Table 1. Construct definitions and measures.

\section{Results}

We conducted CFA using AMOS 25 for the fit assessment of the measurement model. We employed a bootstrapping method (1,000 repetitions) to test the model. Two hundred and fifty or more bootstrap samples are considered to be relevant for the estimation (Nevitt \& Hancock, 2004). Model-fit measures commonly used to evaluate the model's overall goodness-of-fit are the ratio of $\chi 2$ statistic to degrees-of-freedom (df), goodness-of-fit index (GFI), adjusted goodness-of-fit index (AGFI), normalized fit index (NFI), TLI, comparative fit index (CFI), and RMSEA. In this study, we relied on the $\chi 2$ statistic and the RMSEA, NNFI, CFI, and SRMR (Bagozzi \& Yi, 2012). Since our measurement model met the criteria for a good fit (CFI $=0.951$, 
TLI $=0.943$, RMSEA $=0.051$, we went ahead to test for reliability, convergent validity, and discriminant validity. This was achieved using Anderson and Gerbing's (1988) two-stage approach. Initially, the convergent and discriminant validity of the measurement model using CFA were tested. Subsequently, the hypothesized model was compared with alternate models based on fit measures and significance of constructs. Measures of the validity and reliability of the measurement model are shown in Table 2.

\begin{tabular}{|c|c|c|c|c|c|c|c|c|}
\hline & CR & AVE & MSV & WE & OI & CY & CB & EB \\
\hline WE & .889 & .542 & .528 & .736 & & & & \\
\hline OI & .938 & .754 & .528 & $.726^{* * * *}$ & .868 & & & \\
\hline $\mathrm{CY}$ & .805 & .455 & .059 & $-.244^{* * * *}$ & $-.220^{* *}$ & .675 & & \\
\hline CB & .783 & .482 & .239 & $-.489^{* * * *}$ & $-.446^{* * *}$ & $.229^{*}$ & .694 & \\
\hline EB & .800 & .509 & .194 & $.361^{* * *}$ & $.441^{* * *}$ & -.085 & $-.385^{* * * *}$ & .714 \\
\hline
\end{tabular}

Note. $\mathrm{N}=201 ;{ }^{* * *} \mathrm{p}<0.01 ;{ }^{* *} \mathrm{p}<0.05 ;{ }^{*} \mathrm{p}<0.10 ;$ CR: Composite reliability; AVE: Average variance extracted; MSV: Maximum shared variance; WE: Work Engagement; OI: Organizational Identification; CY: Cyberloafing; EB: Enabling Bureaucracy; CB: Coercive Bureaucracy

Table 2. Inter construct correlations

In order to test the convergent validity of scale, Fornell and Larcker (1981) gave three criteria: (a) factor loadings should be greater than 0.70, (b) composite reliabilities (CR) should be greater than 0.70 , and (c) average variance extracted (AVE) should be greater than 0.50 . As Table 2 indicates, values of CR are above the recommended cut-off of 0.7 (Hair, Black, Babin, \& Anderson, 2010). Moreover, if AVE is below 0.5, but composite reliability is greater than 0.6, the convergent validity is considered to be adequate (Fornell \& Larcker, 1981). The measures shown in Table 2 meet these criteria. Discriminant validity was assessed using a criterion that the square root of AVE should exceed the correlations between a construct and other constructs (Fornell \& Larcker, 1981). In addition, almost all the values of Maximum Shared Variance (MSV) are greater than AVE, which is another test for establishing discriminant validity. These two tests corroborated the adequacy of our measurement scales.

To test the common method bias, we used Harman's single-factor test, which advocates that variance explained by the single factor should be less than 50 per cent (Harman, 1960). Our model showed 26.71 per cent of variance, which suggests that common method bias was not present. Next, we proceeded to test our hypothesized model. The model was tested using the maximum likelihood estimation. The structural model (Figure 1) was compared with five other competing models, which are shown below (Figure 2 to Figure 7). Although fit indices are widely accepted way of establishing the fit of the research model, we followed Werner and Schermelleh-Engel (2010) method of comparing different plausible models to further establish the strength of our proposed model. There are studies (e.g., Aghaz \& Sheikh, 2016), which has indicated the relationship between work-related aspects and cyberloafing. Further, there are studies which stated that cyberloafing can impact work-related outcomes such as work engagement (e.g., Lim \& Chen, 2012; Zhao, Wayne, Glibkowski \& Bravo, 2007). Acknowledging these studies, and considering the possibilities of other models and in line with Werner and Schermelleh-Engel (2010), we wanted to check how our research model fare against these models to further establish the robustness of our model. 


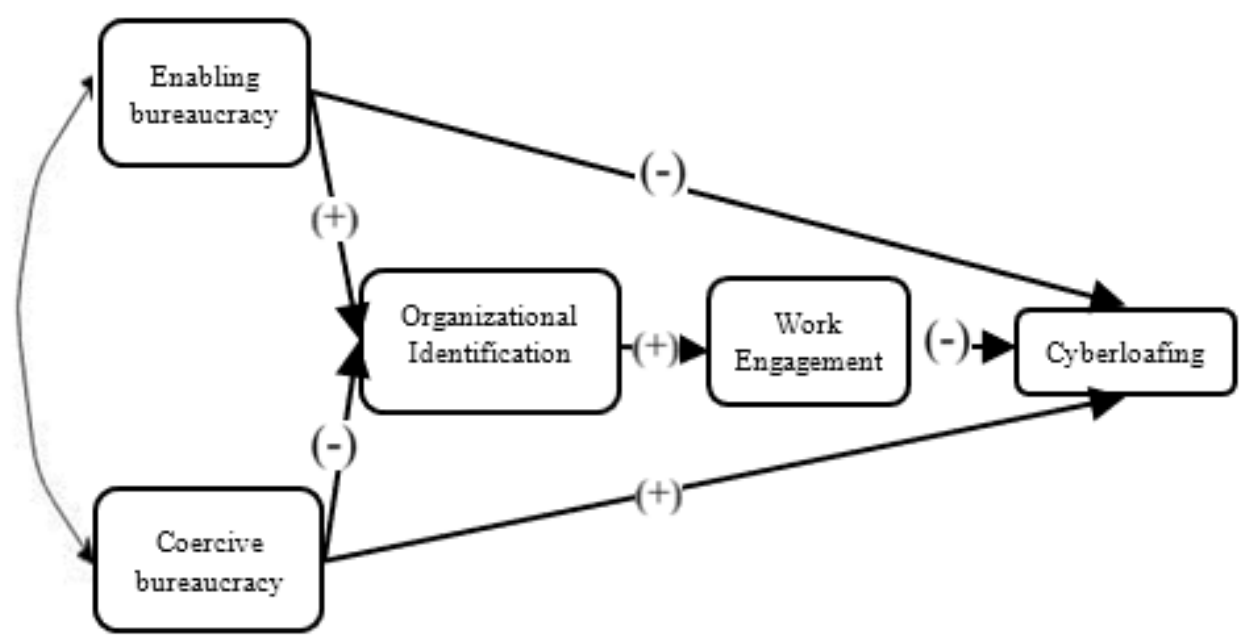

Figure 2: Hypothesized Model

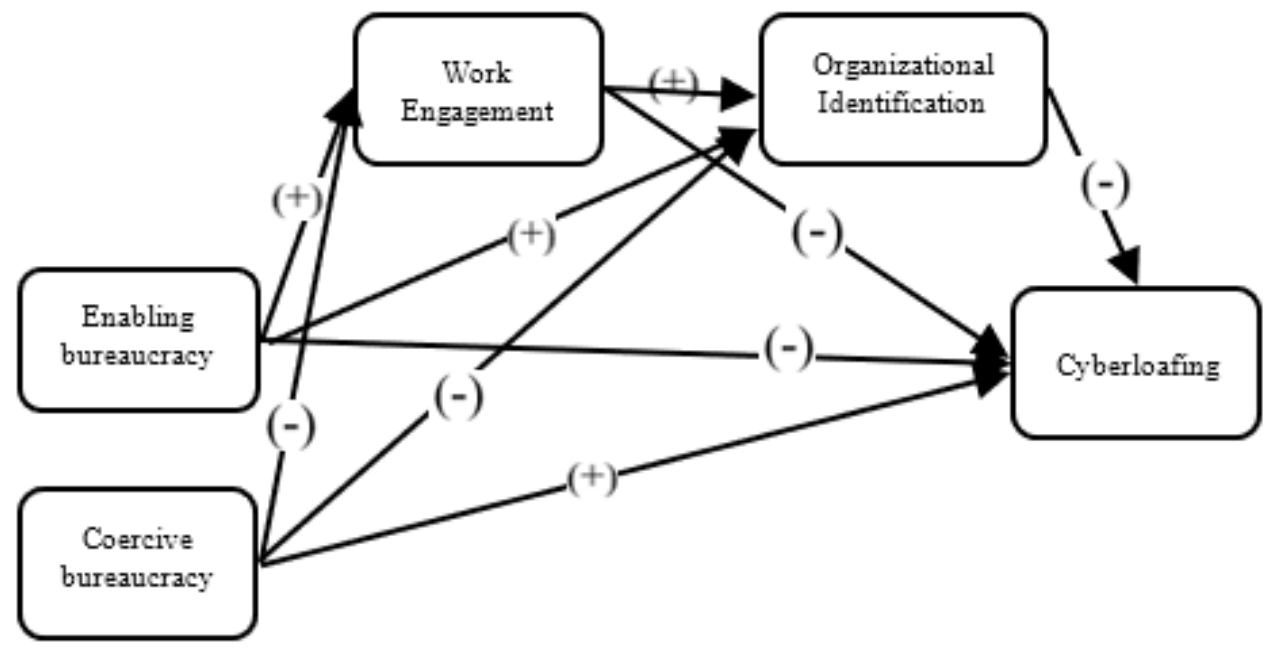

Figure 3: Alternate Model 1

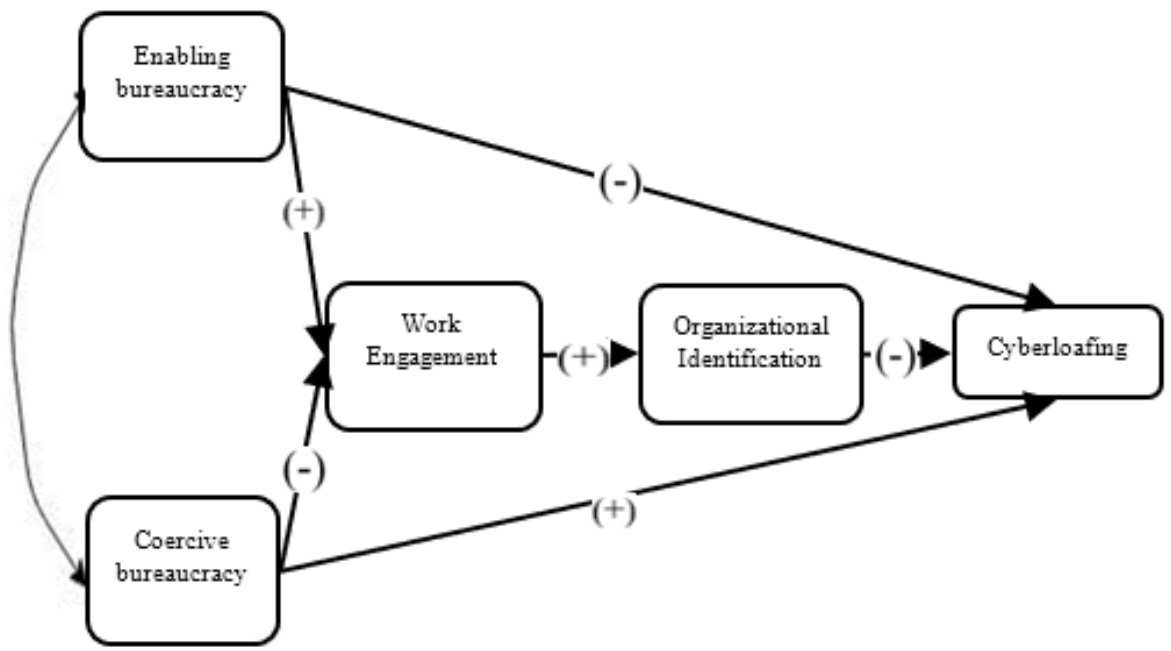

Figure 4: Alternate Model 2 


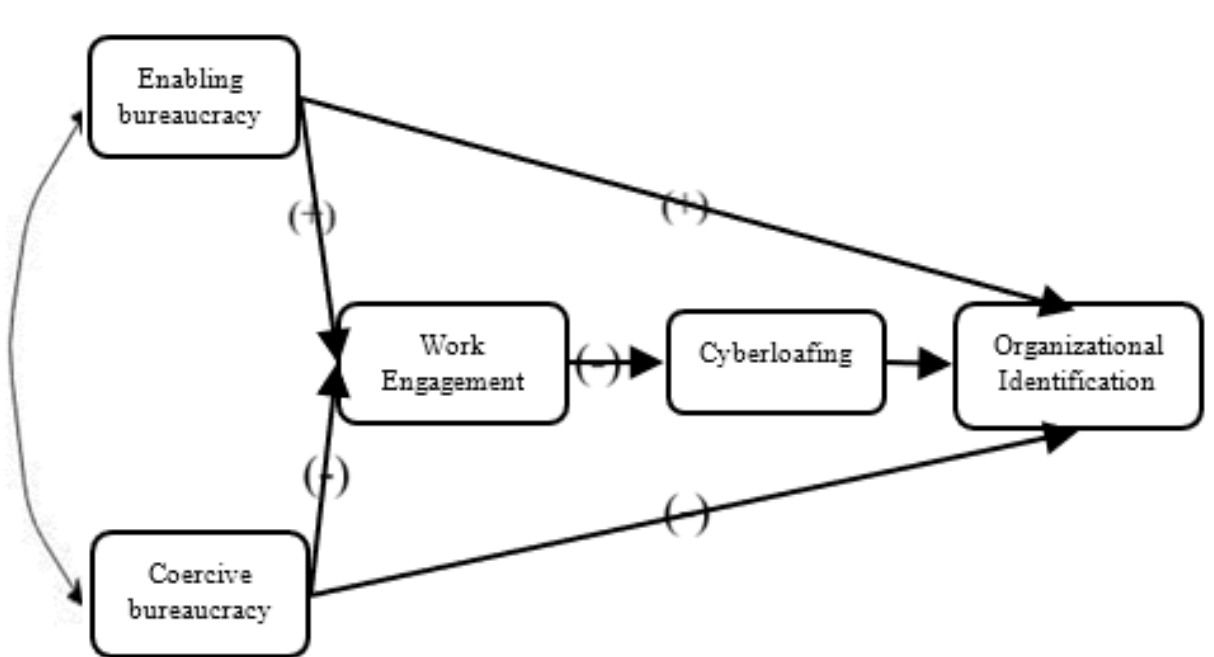

Figure 5: Alternate Model 3

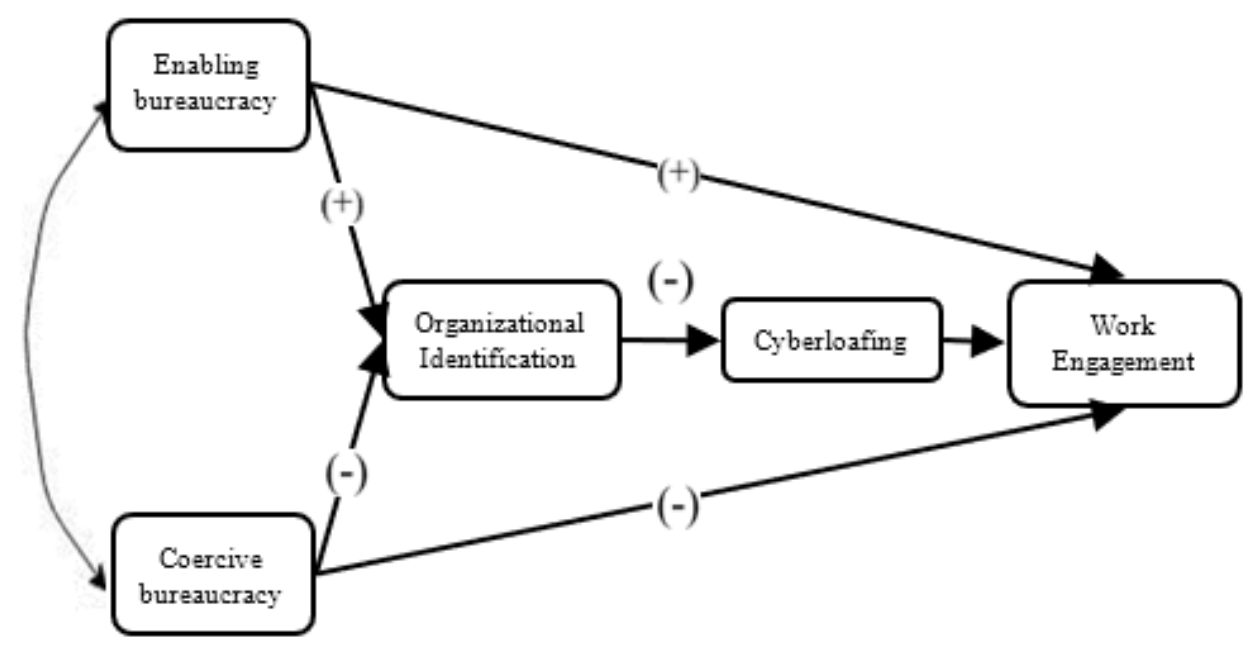

Figure 6: Alternate Model 4

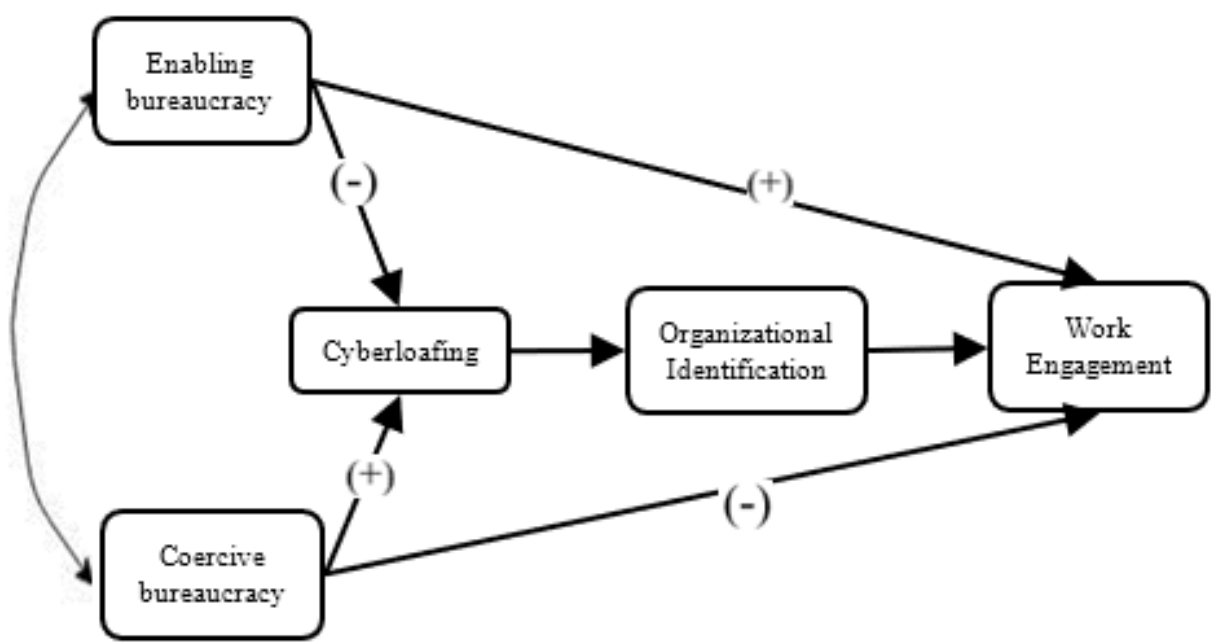

Figure 7: Alternate Model 5

Note: Relationships shown in figures 2 to 7 are depicting direct relationship. 
Based on West, Taylor, and Wu's (2012) recommendation, fit statistics were used to compare different models rather than using a specific cut off standards. The results showed that the hypothesized model has a better fit in comparison to most of the other models. Values are shown in Table 3.

\begin{tabular}{lccccccc}
\hline \multicolumn{1}{c}{ Model } & GFI & AGFI & Chi-square/df & RMSEA & CFI & TLI & SRMR \\
\hline Hypothesised model & 0.848 & 0.789 & 1.427 & 0.046 & 0.929 & 0.907 & 0.056 \\
Alternate Model 1 & 0.846 & 0.787 & 1.450 & 0.047 & 0.925 & 0.902 & 0.061 \\
Alternate Model 2 & 0.850 & 0.791 & 1.422 & 0.046 & 0.930 & 0.908 & 0.056 \\
Alternate Model 3 & 0.831 & 0.766 & 1.633 & 0.056 & 0.894 & 0.861 & 0.077 \\
Alternate Model 4 & 0.822 & 0.757 & 1.713 & 0.060 & 0.879 & 0.844 & 0.078 \\
Alternate Model 5 & 0.838 & 0.775 & 1.545 & 0.052 & 0.909 & 0.881 & 0.087 \\
\hline
\end{tabular}

Note. N=201; GFI: Goodness of fit index; AGFI: Adjusted goodness of fit index; RMSEA: Root mean square error of approximation; CFI: Comparative fit index; TLI: Tucker Lewis index; SRMR: Standardized root mean squared residual

\section{Table 3. Comparison of models}

Education, personality, job type, number of hours working per week, size of the organization, income, and job position were added as control variables. Among them, education, personality, job position, and job type were not found to have any effect on the results, while job type was found to have a direct effect on cyberloafing $(\beta=-0.167, p=0.020$, lower $C I=-0.286$, upper $C I=-0.033$ ). Coming to the indirect effect, size of the organization was found to have an effect on cyberloafing $(\beta=0.036, p=0.035$, lower $\mathrm{CI}=0.002$, upper $\mathrm{CI}=0.113)$. Also, two aspects of personality, agreeableness $(\beta=0.028, p=0.032$, lower $C I=-0.120$, upper $\mathrm{CI}=-0.001)$ and extroversion $(\beta=0.031, p=0.046$, lower $\mathrm{CI}=0.001$, upper $\mathrm{CI}=0.099)$ were found to have a positive indirect effect on cyberloafing. Hypothesis 1a did not get support as the direct correlation between coercive bureaucracy and cyberloafing was not found to be significant $(p=0.262)$. Similarly, hypothesis $1 \mathrm{~b}$ was not supported as the direct correlation between enabling bureaucracy and cyberloafing was not found to be significant ( $p=0.565)$. Hypothesis 2a was supported as the direct relationship between coercive bureaucracy and organizational identification was found to be significant $(\beta=-0.304, p=0.002$, lower $C I=-0.517$, upper $C I=-0.150$ ). Similarly, hypothesis $2 b$ was supported as the direct correlation between enabling bureaucracy and organizational identification was found to be significant $(\beta=0.330, p=0.003$, lower $\mathrm{CI}=0.159$, upper $\mathrm{CI}=0.496)$. Hypothesis 3 received support as the direct correlation between organizational identification and work engagement was significant $(\beta=0.690, p=0.002$, lower $C I=0.579$, upper $C I=0.783)$. Hypothesis 4 , though rejected, was found to have a weak significance at 10 per cent confidence interval $(\beta=-0.228, p=0.057)$. Hypothesis 5a, which states that coercive bureaucracy has a positive indirect effect on cyberloafing through organizational identification and work engagement, received support as the relation was found to be significant $(\beta=0.048, p=0.035$, lower $\mathrm{CI}=0.003$, upper $\mathrm{CI}=0.134)$. Similarly, hypothesis $5 \mathrm{~b}$ which states that enabling bureaucracy has a negative indirect effect on cyberloafing through organizational identification and work engagement received support as the relation was found to be significant $(\beta=-0.052, p=0.038$, lower $\mathrm{CI}=-0.132$, upper $\mathrm{CI}=-0.004)$. The results are indicated in Figure 8. 


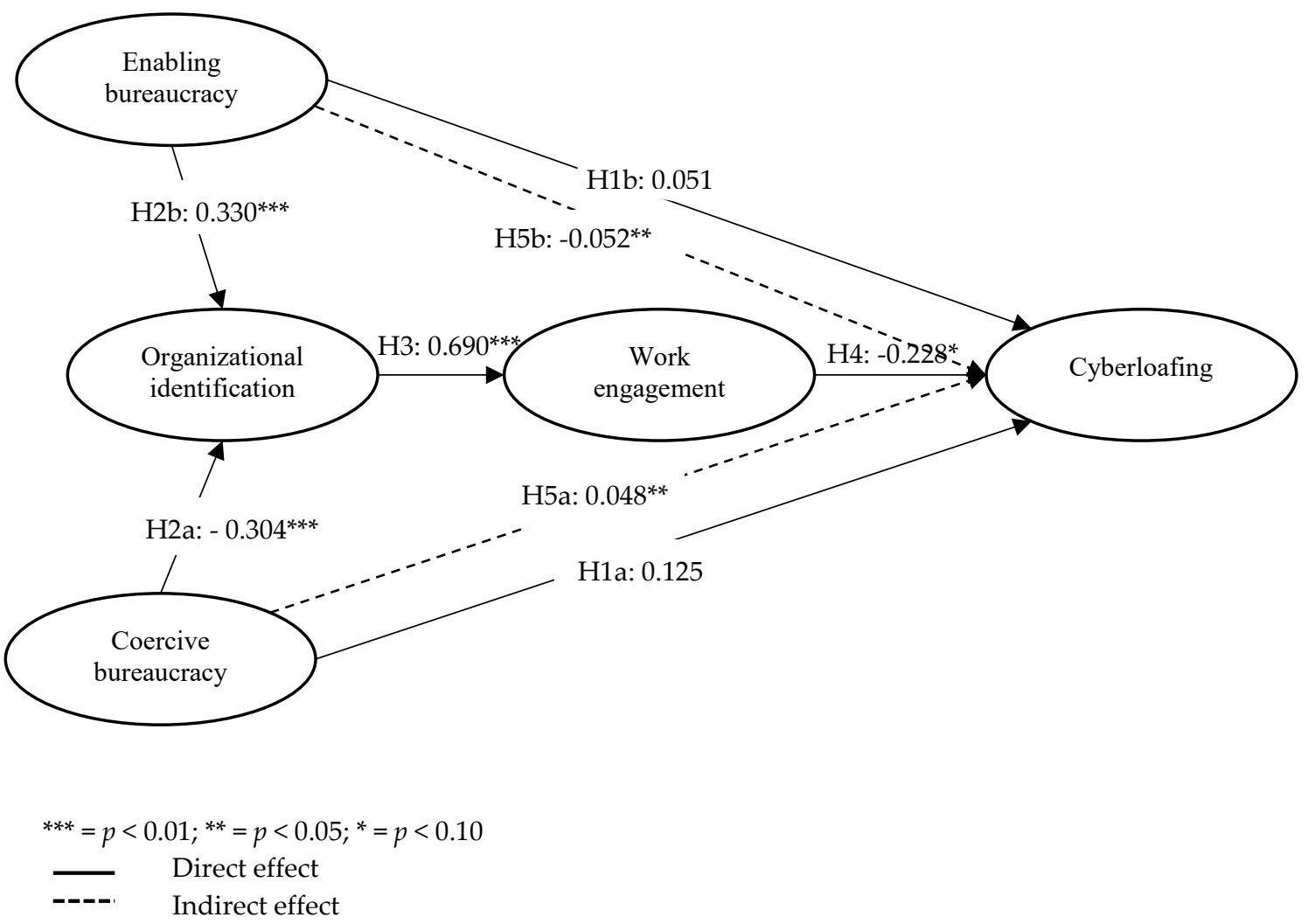

Figure 8: Path diagram of the hypothesized model

\section{Discussion}

The study is based on identifying how the ambivalent perceptions of employees toward their organizational structures impact their indulgence in deviant behaviour. Perceptions of bureaucracy were studied based on two prominent features of bureaucracy-formalization and centralization. Both the features were perceived by respondents as either coercive or enabling, which makes their perceptions ambivalent toward bureaucracy. The effect of these perceptions on serious cyberloafing, which is a deviant behaviour, was evaluated. Findings from the study show that hypotheses $1 \mathrm{a}$ and $1 \mathrm{~b}$, that is, the presence of a direct relationship of enabling and coercive bureaucracy with cyberloafing came out as nonsignificant. The reason for this result can be understood through the theory of planned behaviour (TPB). As per the theory, behaviour is caused due to three prominent antecedents, namely, subjective social norms, attitudes, and perceived behavioural control (Ajzen, 1985). As per Ajzen (1985), the higher the favourable attitude of an employee and the higher the perception of ease in showcasing a behaviour, the higher will be the behavioural intent. Attitude mediates the relationship between perceived control and behavioural intent. Therefore, a direct relationship, as suggested in hypotheses $1 \mathrm{a}$ and $1 \mathrm{~b}$, came out to be insignificant.

Hypotheses $2 a$ and $2 b$, that is, the direct relationship between enabling and coercive bureaucracy, and organizational identification came out to be significant. As given in the literature, organizational identification occurs when an employee feels a sense of belongingness with the organization, and this is possible only when an employee perceives the functioning of the organization as a facilitator towards his/her work. Hypothesis 3 , that is, the direct positive relationship between organizational identification and work engagement validates the study done by Karanika-Murray et al. (2015), and showed a significant result. 
Having a strong bond with the organization indicates a strong bond with the work as well because organizational identification develops a sense of responsibility toward the organization, which will be fulfilled by the employees through their work. These two attitudinal variables, when combined, depict an employee's relationship or bond with the organization, which further influences the employee behavioural outcomes (Karanika-Murray et al., 2015). This brings us to hypothesis 4 , which states that work engagement will negatively affect cyberloafing activities. As discussed earlier, work engagement is a work-related motivational state of mind that makes employee highly involved in work and persistent in their efforts (Schaufelli et al., 2002). This high engagement with work may supersede the desire to involve in deviant behaviour and may even reduce the impact of Internet addiction. Another reason for explaining the relationship between work engagement and cyberloafing activities is boredom and stress occurring in the workplace. For example, engaged employees do not feel bored and maintain a constant involvement with work (Van Wyk, de Beer, Pienaar, \& Schaufeli, 2016). Due to this, the tendency to involve in cyberloafing due to boredom will be reduced (Pindek et al., 2018). Thus, work engagement is negatively related to cyberloafing. Hypothesis 5 states an indirect relationship between perception of bureaucracy and cyberloafing via organizational identification and work engagement. The two attitudinal variables play a significant role in establishing this indirect relationship. This relationship is also supported by the TPB, where attitudes (organizational identification and work engagement) create an indirect effect between perceived control (bureaucracy) and behaviour (cyberloafing). Furthermore, as stated by Kim and Byrne (2011), employees engage in cyberloafing due to the internal processes and their perception of unfair treatment by the organization. A one shoe fits all approach may not work in organizations (Jha, Pandey \& Varkkey, 2019; Pandey 2018). While bureaucratic structures are formed with the objective of bringing formalized procedures and norms to control any type of deviance (Adler, 2012), the increase in the control itself leads to an increase in cyberloafing activity. Therefore, people under the perception of the coercive organizational structure may feel alienated (McGuigan, 2005), so much so that it will directly affect their relationship with the organization and may subsequently reduce their engagement with their work. For such people, working will need higher mental efforts, and they may tend to feel stressed (Koay et al., 2017b). In such a case, deviant behaviour comes to their rescue, helps them in releasing their worries, and makes them feel refreshed (Case \& Young, 2002). However, these deviant behaviours negatively impact organizational productivity. Kim (2018), in his HBR article about millennials has addressed this issue. Since the entry of millennials into the workforce, who considers technology as something indispensable in their daily activities, it is necessary to understand their perception of work. Use of control mechanisms like deterrence may backfire and can lead to dysfunctional outcomes. Therefore, it is necessary to mutually decide upon the policies taking into account the needs of both the employees as well as the organization. So, there is a need for managers to keep a balance between employees' necessity to indulge in minor cyberloafing and their productivity level while keeping a check on major cyberloafing activities. The results also validated the containment theory by empirically proving how outer containment (perception of enabling bureaucracy) along with internal containments (organizational identification and work engagement) prevent deviant behaviour like cyberloafing activity.

\subsection{Theoretical Contributions}

Our study contributes to the bureaucracy as well as cyberloafing literature in four keyways. 
First, containment theory (Reckless, 1961), a criminology theory, is used for the first time in the context of information system studies for empirical analysis. By using deviance inducing and deviance containing variables from the organizational context, we accommodated the theory to the organizational setting. Drawing on the theory, we argue that pull and push factors that trigger the deviant behaviour (Flexon, 2014) were represented by the perception of coercive bureaucracy variable. Similarly, the outer containment factor, that prevents deviant behaviour, was represented by perception of enabling bureaucracy. Further, the inner containment was represented using organizational variables such as organizational identification and work engagement. Future studies may investigate further into other organizational constructs that may potentially serve as outer and inner containments. Our contribution will provide IS researchers a platform to understand other kinds of deviant cyber behaviours using the containment theory.

Second, in the IS literature, cyberloafing studies have used theories from various areas such as behavioural theory, social theory, criminology theory etc. (Refer Appendix I). For example, Jia, Jia and Karau (2013) and Ugrin and Pearson (2013) have used General Deterrence theory to propose that using coercive methods and instilling fear in employees, cyberloafing behaviour can be controlled. On the contrary, by adopting the containment theory from criminology, our study adds to the existing literature on cyberloafing by establishing that there are non-coercive ways to contain cyberloafing behaviour. By adopting this theory, we empirically proved that the enabling perception of bureaucracy (i.e., an outer containment) along with the organizational identification and work engagement (i.e., inner containments) help in containing cyberloafing. As said by Reckless (1967), "if a group or organization can get its members to internalize their rules, it would be doing an excellent job of containing" (p. 470) the deviant behaviour. Thus, by underscoring the importance of non-coercive control mechanisms, ours is the first study to extend the theory on cyberloafing using containment theory.

Third, IS as a multi-disciplinary field deals with problems in several contexts such as organizational, sociological, and psychological, among others. Particularly, while studying an organization, several aspects of it such as culture, structure, communication, and processes play a critical role. Since the organizational structure governs the workflow of an organization, it controls how a technology will be implemented, used and benefited within the organization. Acknowledging such prominence of organizational structure, many IS studies have undertaken investigations related to it. For instance, in the organizational context, studies have found that bureaucratic structure restricts the adoption of technology (Hall \& Khan, 2002) and ERP implementation (Morton \& Hu, 2008). Baroudi and Lucas (1994) argue that bureaucracy creates bottlenecks, and technology can help remove it (Baroudi \& Lucas, 1994). Similarly, studies have acknowledged the role of centralized organizational structure on knowledge management (Chen \& Huang, 2007). Further, Vaast and Binz-Scharf (2008) found that through technology, the negative effects of bureaucratic structure can be nullified. More importantly, the above-mentioned studies of bureaucracy in IS have ignored the fact that bureaucracy is perceived differently by each employee. Although bureaucratic structure as an antecedent is prominently studied in IS literature, there is a conspicuous dearth of studies on the perception of organizational structure and cyberloafing. Acknowledging this gap, we delved in understanding the role of ambivalent perception of bureaucracy as an antecedent to the technology-related deviant behaviour (i.e., cyberloafing). 
Finally, our study provides a systematic literature review of the cyberloafing literature, from which it can be seen that the literature mainly consists of studies based on the employee's perception, followed by attitude and behaviours. Such a comprehensive review of cyberloafing literature was missing in the extant studies. We strongly believe that future studies may benefit from the consolidated list provided in Annexure-II. Our study adds to the literature of cyberloafing by studying the impact of unexplored variables such as perception of bureaucracy and two important attitudes, i.e. organizational identification and work engagement on cyberloafing behaviour.

\subsection{Practical Contributions}

Paper also offers contributions to the practitioners in several key ways. From the present study, it was also evident that it is not only the increase in accessibility to the Internet that causes cyberloafing behaviours but also a mix of perception and attitudes. Employees perceiving the organizational structure to be coercive identify themselves less with the organization who in turn tends to be less engaged in their work, and engage in cyberloafing activities. The extant studies have suggested that managers should advance toward adopting a post-bureaucratic or e-bureaucratic structure (Osborne \& Plastrik, 1997). However, from our present study, it is found that even in the presence of a bureaucratic structure, employee engagement and identification may be present if their perception towards such structure is positive, which in turn will reduce the cyberloafing activities. To develop and maintain such a setup in an organization, managers must ensure that two-way dialogue is set up to understand the perception of the employees about such structural interventions. A wellintended initiative by policymakers can have perilous effects if the perceptions are not managed well. Managers must, therefore, communicate the reasons and procedures of structural interventions present in the organizational structure.

\section{Limitations and Future Directions}

This study, while providing insightful results, is not devoid of limitations, which need to be accounted for in further studies. First, methodologically, the study did a cross-sectional analysis of employees, which may not provide the perspective of the manager. A multilevel study would be helpful to know the macro-level perception of managers and policymakers, who are responsible for setting up the organizational structure toward the causes and consequences of cyberloafing. Second, the majority of the cyberloafing literature is based on the survey method, and researchers should further understand this phenomenon using different methodological techniques. For example, experiential sampling method may be used to study when during a working day an employee indulges in cyberloafing the most. This will help in finding specific interventions based on the intensity of the cyberloafing at a given time. Experiential sampling is used to study the experience of engaging in activities in everyday life and to understand the dynamics of emotions and other subjective states (Farnworth, Mostert, Harrison, \& Worrell, 1996). Moreover, other techniques such as interviews and focus groups may be used to understand these behaviours in depth. Third, our study considers only serious cyberloafing. There is a need for understanding the beneficial aspects of cyberloafing in addition to considering it as a deviant behaviour alone. Few studies have studied cyberloafing to be a coping mechanism, and further debates about its positive aspects will help us to know more about the phenomena. Fourth, the sample size is skewed towards male respondents, which made it difficult to test the effect of gender on cyberloafing activities. Gender-specific studies can throw more light on this. Future studies may contribute to the organizational 
structure literature by studying how the perceptions of an organizational structure differ between male and female. Fifth, start-ups have an evolving organizational structure, and they function in an organic way that provides flexibility to them (Freeman \& Engel, 2007). Since our study involves firms with different organizational size, our findings from this study should be generalized with caution. Sixth, our study does not take into account the possibility that an individual may consider some aspects of bureaucracy as enabling, while other aspects as coercive. This possibility needs to be explored in future studies. Finally, Annexure I, developed from the systematic literature review, provides a consolidated view of the studies done in various aspects of cyberloafing. While studies on perceptions and attitudes are studied to quite an extent, the role of emotions and skills is yet to be explored in depth.

\section{Conclusion}

Cyberloafing is an issue that can cause huge productivity losses to the companies, and it has become a ubiquitous deviant behaviour because of the rapid penetration of smartphones and the Internet. In this study, we dug deeper to understand how perceptions of bureaucracy by employees can have an impact on their cyberloafing activities. Drawing on the containment theory, we inquired into the role of ambivalent perceptions of bureaucracy using the push and pull factors. When the perception of bureaucracy is enabling (outer containment), it reduces cyberloafing behaviour of the employees in the presence of self-identification with the organization and significant engagement with the work (inner containment). On the other hand, the perception of employees toward bureaucracy as a coercive structure leads to a reduction in the organizational identification of the employees, which subsequently affects their work engagement, and finally induces them to indulge in cyberloafing activities. As found from the results, the study empirically established the serial mediation of perceptions of bureaucracy, that is, enabling $(\beta=-0.052)$ and coercive $(\beta=0.048)$, on cyberloafing through organizational identification and work engagement. The insights from the study will be an important step in understanding the phenomenon of cyberloafing. Particularly, it enlightens policymakers as well corporate practitioners about the role of perceptions regarding bureaucracy in dealing with cyberloafing.

\section{References}

Adler, P. S. (2012). Perspective---The Sociological Ambivalence of Bureaucracy: From Weber via Gouldner to Marx. Organization Science, 23(1), 244-266. https://doi.org/10.1287/orsc.1100.0615

Adler, P. S., \& Borys, B. (1996). Two Types of Bureaucracy: Enabling and Coercive. Administrative Science Quarterly, 41(1), 61-89. https://doi.org/10.2307/2393986

Aghaz, A., \& Sheikh, A. (2016). Cyberloafing and job burnout: An investigation in the knowledgeintensive sector. Computers in Human Behavior (Vol. 62). https://doi.org/10.1016/j.chb.2016.03.069

Ahmad, Z., \& Jamaluddin, H. (2010). Computer usage policy and employees' attitude towards cyberloafing. In Technology Innovation and Industrial Management 2010 Conference (TIIM 2010).

Ajzen, I. (1985). From Intentions to Actions: A Theory of Planned Behavior BT - Action Control: From Cognition to Behavior. In J. Kuhl \& J. Beckmann (Eds.) (pp. 11-39). Berlin, Heidelberg: Springer Berlin Heidelberg. https://doi.org/10.1007/978-3-642-69746-3_2 
Akers, R. L. (1994). Criminological theories: introduction and evaluation. Los Angeles, Calif.: Roxbury Pub. Co

Alfes, K., Truss, C., Soane, E. C., Rees, C., \& Gatenby, M. (2013). The Relationship Between Line Manager Behavior, Perceived HRM Practices, and Individual Performance: Examining the Mediating Role of Engagement. Human Resource Management, 52(6), 839859. https://doi.org/10.1002/hrm.21512

Alias, M., Mohd Rasdi, R., Ismail, M., \& Abu Samah, B. (2013). Predictors of workplace deviant behaviour: HRD agenda for Malaysian support personnel. European Journal of Training and Development, 37(2), 161-182. https://doi.org/10.1108/03090591311301671

Anandarajan, M., \& Simmers, C. A. (2005). Developing Human Capital through Personal Web Use in the Workplace: Mapping Employee Perceptions. Communications of the Association for Information Systems, 15(1). https://doi.org/10.17705/1CAIS.01541

Anderson, J., \& Gerbing, D. W. (1988). Structural Equation Modeling in Practice: A Review and Recommended Two-Step Approach. Psychological Bulletin, 103(3), 411-423. https://doi.org/10.1037/0033-2909.103.3.411

Arches, J. (1991). Social structure, burnout, and job satisfaction. Social Work. United Kingdom: Oxford University Press.

Arciniega, L. M., Stanley, L. J., Puga-Méndez, D., Obregón-Schael, D., \& Politi-Salame, I. (2017). The Relationship Between Individual Work Values and Unethical Decision-Making and Behavior at Work. Journal of Business Ethics. https://doi.org/10.1007/s10551-017-3764-3

Ashforth, B. E., \& Mael, F. (1989). Social Identity Theory and the Organization. The Academy of Management Review, 14(1), 20-39. https://doi.org/10.2307/258189

Askew, K., Buckner, J. E., Taing, M. U., Ilie, A., Bauer, J. A., \& Coovert, M. D. (2014). Explaining cyberloafing: The role of the theory of planned behavior. Computers in Human Behavior, 36, 510-519. https://doi.org/10.1016/j.chb.2014.04.006

Bagozzi, R. P., \& Yi, Y. (1988). On the evaluation of structural equation models. Journal of the Academy of Marketing Science, 16(1), 74-94. https://doi.org/10.1007/BF02723327

Bagozzi, R. P., \& Yi, Y. (2012). Specification, evaluation, and interpretation of structural equation models. Journal of the Academy of Marketing Science, 40(1), 8-34. https://doi.org/10.1007/s11747-011-0278-x

Bakker, A. B., \& Demerouti, E. (2008). Towards a model of work engagement. Career Development International, 13(3), 209-223. https://doi.org/10.1108/13620430810870476

Baroudi, J., \& Lucas, H. C. (1994). The Role of Information Technology in Organization Design. Journal of Management Information Systems, 10(4), 9-23. https://doi.org/10.1080/07421222.1994.11518018

Baturay, M. H., \& Toker, S. (2015). An investigation of the impact of demographics on cyberloafing from an educational setting angle. Computers in Human Behavior, 50, 358366. https://doi.org/https://doi.org/10.1016/j.chb.2015.03.081

Beebe, N., \& Rao, S. (2005). Using Situational Crime Prevention Theory to Explain the Effectiveness of Information Systems Security. In Proceedings of the 2005 SoftWars Conference. 
Belanger, F., \& Van Slyke, C. (2002). Abuse or Learning? Commun. ACM, 45(1), 64-65. https://doi.org/10.1145/502269.502299

Bendix, R. (1960). Social Stratification and the Political Community. European Journal of Sociology, 1(2), 181-210. https://doi.org/10.1017/S0003975600000138

Bennis, W. G. (1969). Post-bureaucratic leadership. Trans-Action, 6(9), 44-52. https://doi.org/10.1007/BF02819884

Benkhoff, B. (1997). Disentangling organizational commitment: The dangers of the OCQ for research and policy. Personnel Review, 26(1/2), 114-131. https://doi.org/10.1108/00483489710157823

Blanchard, A. L., \& Henle, C. A. (2008). Correlates of Different Forms of Cyberloafing: The Role of Norms and External Locus of Control. Comput. Hum. Behav., 24(3), 1067-1084. https://doi.org/10.1016/j.chb.2007.03.008

Bonjean, C. M., \& Grimes, M. D. (1970). Bureaucracy and Alienation: A Dimensional Approach*. Social Forces, 48(3), 365-373. Retrieved from http://dx.doi.org/10.2307/2574655

Bretschneider, S., \& Parker, M. (2016). Organization formalization, sector and social media: Does increased standardization of policy broaden and deepen social media use in organizations? Government Information Quarterly, 33(4), 614-628. https://doi.org/10.1016/j.giq.2016.09.005

Brown, M. E. (1969). Identification and some conditions of organizational involvement. Administrative Science Quarterly, 14(3), 346-355. https://doi.org/10.2307/2391129

Case, C. J., \& Young, K. S. (2002). Employee Internet Management: Current Business Practices and Outcomes. CyberPsychology \& Behavior, 5(4), 355-361. https://doi.org/10.1089/109493102760275608

Chang, K., \& Smithikrai, C. (2010). Counterproductive behaviour at work: an investigation into reduction strategies. The International Journal of Human Resource Management, 21(8), 1272-1288. https://doi.org/10.1080/09585192.2010.483852

Chen, J. V, Chen, C. C., \& Yang, H. (2008). An empirical evaluation of key factors contributing to internet abuse in the workplace. Industrial Management $\mathcal{E}$ Data Systems, 108(1), 87-106. https://doi.org/10.1108/02635570810844106

Cheng, B., Zhou, X., Guo, G., \& Yang, K. (2018). Perceived Overqualification and Cyberloafing: A Moderated-Mediation Model Based on Equity Theory. Journal of Business Ethics. https://doi.org/10.1007/s10551-018-4026-8

Clawson, D. (1980). Bureaucracy and labor process: The transformation of U.S. industry, 1860-1920. Monthly Review Press, New York and London.

Chen, C.-J., \& Huang, J.-W. (2007). How organizational climate and structure affect knowledge management-The social interaction perspective. International Journal of Information Management, $27(2)$, 104-118. https://doi.org/https://doi.org/10.1016/j.ijinfomgt.2006.11.001 
Christian, M. S., \& Slaughter, J. E. (2007). Work engagement: a meta-analytic review and directions for research in an emerging area. In Academy of Management Proceedings (Vol. 2007, pp. 1-6).

Cook, J., \& Wall, T. (1980). New work attitude measures of trust, organizational commitment and personal need non-fulfilment. Journal of Occupational Psychology, 53(1), 39-52. https://doi.org/10.1111/j.2044-8325.1980.tb00005.x

Csikszentmihalyi, M. (1997). Finding flow: The psychology of engagement with everyday life. Finding flow: The psychology of engagement with everyday life. New York, NY, US: Basic Books.

Dalal, R. S., Brummel, B. J., Wee, S., \& Thomas, L. L. (2008). Defining Employee Engagement for Productive Research and Practice. Industrial and Organizational Psychology, 1(1), 5255. https://doi.org/10.1111/j.1754-9434.2007.00008.x

Damanpour, F. (1991). Organizational Innovation: A Meta-Analysis of Effects of Determinants and Moderators. The Academy of Management Journal, 34(3), 555-590. https://doi.org/10.2307/256406

Deming, W. E. (1986). Out of the crisis. Cambridge, Mass.: Massachusetts Institute of Technology, Center for Advanced Engineering Study.

Dodder, R. A., \& Long, J. R. (1980). Containment Theory Reevaluated: An Empirical Explication. Criminal Justice Review, 5(2), 74-84. https://doi.org/10.1177/073401688000500211

Driscoll, D. L. (2011). Introduction to primary research: Observations, surveys, and interviews. Writing spaces: Readings on writing, 2, 153-174.

Dutton, J. E., Dukerich, J. M., \& Harquail, C. V. (1994). Organizational Images and Member Identification. Administrative Science Quarterly, 39(2), 239-263. https://doi.org/10.2307/2393235

Efraty, D., \& Wolfe, D. M. (1988). The effect of organizational identification on employee affective and performance responses. Journal of Business and Psychology, 3(1), 105-112. https://doi.org/10.1007/BF01016752

Epitropaki, O. (2013). A multi-level investigation of psychological contract breach and organizational identification through the lens of perceived organizational membership: Testing a moderated-mediated model. Journal of Organizational Behavior, 34(1), 65-86. https://doi.org/10.1002/job.1793

Farnworth, L., Mostert, E., Harrison, S., \& Worrell, D. (1996). The experience sampling method: its potential use in occupational therapy research. Occupational Therapy International, 3(1), 1-17. https://doi.org/10.1002/oti.23

Flexon, J. L. (2014). Containment Theory. In The Encyclopedia of Theoretical Criminology (pp. 15). American Cancer Society. https://doi.org/10.1002/9781118517390.wbetc023

Fornell, C., \& Larcker, D. F. (1981). Structural Equation Models with Unobservable Variables and Measurement Error: Algebra and Statistics. Journal of Marketing Research, 18(3), 382388. https://doi.org/10.2307/3150980

Foucault, M. 1979. Discipline and punish: The birth of the prison. New York: Vintage Books. 
Freeman, J., \& Engel, J. S. (2007). Models of Innovation: Startups and Mature Corporations. California Management Review, 50(1), 94-119. https://doi.org/10.2307/41166418

Frug, G. E. (1984). The Ideology of Bureaucracy in American Law. Harvard Law Review, 97(6), 1276-1388. https://doi.org/10.2307/1340969

Garrett, R. K., \& Danziger, J. N. (2008). On Cyberslacking: Workplace Status and Personal Internet Use at Work. CyberPsychology \& Behavior, 11(3), 287-292. https://doi.org/10.1089/cpb.2007.0146

Glaser, B. G. (1963). The local-cosmopolitan scientist. American Journal of Sociology, 69(3), 249259. https://doi.org/10.1086/223583

Gouldner, A. W. (1954). Patterns of industrial bureaucracy. Patterns of industrial bureaucracy. New York, NY, US: Free Press.

Greenberg, D. F. (1977). Delinquency and the age structure of society. Contemporary Crises, 1(2), 189-223. https://doi.org/10.1007/BF00728871

Greene, C. N. (1978). Identification modes of professionals: Relationship with formalization, role strain, and alienation. Academy of Management Journal, 21(3), 486-492. https://doi.org/10.2307/255729

Griffiths, M. D. (2012). Facebook Addiction: Concerns, Criticism, and Recommendations-A Response to Andreassen and Colleagues. Psychological Reports, 110(2), 518-520. https://doi.org/10.2466/01.07.18.PR0.110.2.518-520

Güğerçin, U. (2019). Does techno-stress justify cyberslacking? An empirical study based on the neutralisation theory. Behaviour $\mathcal{E}$ Information Technology, 1-13. https://doi.org/10.1080/0144929X.2019.1617350

Hadlington, L., \& Parsons, K. (2017). Can Cyberloafing and Internet Addiction Affect Organizational Information Security? Cyberpsychology, Behavior, and Social Networking, 20(9), 567-571. https://doi.org/10.1089/cyber.2017.0239

Hair, J. F., Black, W. C., Babin, B. J., \& Anderson, R. E. (2010). Multivariate data analysis: International version. New Jersey, Pearson.

Hall, R. H. (1963). The Concept of Bureaucracy: An Empirical Assessment. American Journal of Sociology, 69(1), 32-40. https://doi.org/10.1086/223508

Hall, R. H. (1968). Professionalization and Bureaucratization. American Sociological Review, 33(1), 92-104. https://doi.org/10.2307/2092242

Hall, D. T., Schneider, B., \& Nygren, H. T. (1970). Personal Factors in Organizational Identification. Administrative Science Quarterly, 15(2), 176-190. https://doi.org/10.2307/2391488

Hall, B., \& Khan, B. (2002). Adoption of New Technology.

Hartline, M. D., Maxham, J. G., \& McKee, D. O. (2000). Corridors of Influence in the Dissemination of Customer-Oriented Strategy to Customer Contact Service Employees. Journal of Marketing, 64(2), 35-50. https://doi.org/10.1509/jmkg.64.2.35.18001

Harman, H. H. (1960). Modern factor analysis. Modern factor analysis. Oxford, England: Univ. of Chicago Press. 
Hatch, M. J., \& Schultz, M. (2004). Organizational identity: A reader. Oxford University Press on Demand.

Hebrew University Of Jerusalem (2019). Databases by subject. Retrieved from http://www.agri.huji.ac.il/library/subjdata_new.html\#multi

Henle, C. A., \& Blanchard, A. L. (2008). The Interaction of Work Stressors and Organizational Sanctions on Cyberloafing. Journal of Managerial Issues, 20(3), 383-400. Retrieved from http://www.jstor.org/stable/40604617

Heffron, F. A. (1989). Organization Theory and Public Organizations: The Political Connection. Prentice Hall.

Hess, P. C. (2006). Bureaucracy and total quality management: A sociological theory of clashing systems, moralities, and knowledge methods (Order No. 3221438). Available from ABI/INFORM Collection; ProQuest Dissertations \& Theses Global. (305355460). Retrieved from https://search.proquest.com/docview/305355460? accountid=47950

Hoy, W. K., \& Sweetland, S. R. (2001). Designing Better Schools: The Meaning and Measure of Enabling School Structures. Educational Administration Quarterly, 37(3), 296-321. https://doi.org/10.1177/00131610121969334

Jackson, S. E., \& Schuler, R. S. (1985). A meta-analysis and conceptual critique of research on role ambiguity and role conflict in work settings. Organizational Behavior and Human Decision Processes, 36(1), 16-78. https://doi.org/10.1016/0749-5978(85)90020-2

Jelinek, R., \& Ahearne, M. (2006). The Enemy within: Examining Salesperson Deviance and its Determinants. Journal of Personal Selling $\mathcal{E}$ Sales Management, 26(4), 327-344. https://doi.org/10.2753/PSS0885-3134260401

Jia, H., Jia, R., \& Karau, S. (2013). Cyberloafing and personality: The impact of the Big Five traits and workplace situational factors. Journal of Leadership $\mathcal{E}$ Organizational Studies, 20(3), 358-365. https://doi.org/10.1177/1548051813488208

Jha, J. K., Pandey, J., \& Varkkey, B. (2019). Examining the role of perceived investment in employees' development on work-engagement of liquid knowledge workers. Journal of Global Operations and Strategic Sourcing. 12(2), 225-245.

Johnson, P., Wood, G., Brewster, C., \& Brookes, M. (2009). The rise of post-bureaucracy: Theorists' fancy or organizational praxis? International Sociology, 24(1), 37-61. https://doi.org/10.1177/0268580908100246

Kakabadse, A. (1986). Organizational Alienation and Job Climate: A Comparative Study of Structural Conditions and Psychological Adjustment. Small Group Behavior, 17(4), 458471. https://doi.org/10.1177/104649648601700406

Karanika-Murray, M., Duncan, N., Pontes, H. M., \& Griffiths, M. D. (2015). Organizational identification, work engagement, and job satisfaction. Journal of Managerial Psychology, 30(8), 1019-1033. https://doi.org/10.1108/JMP-11-2013-0359

Karasek, R., \& Theorell, T. (1990). Healthy work: stress, productivity, and the reconstruction of working life. Basic Books. Retrieved from https://books.google.co.in/books?id=MrXuAAAAMAAJ 
Kehoe, R. R., \& Wright, P. M. (2010). The Impact of High-Performance Human Resource Practices on Employees' Attitudes and Behaviors. Journal of Management, 39(2), 366-391. https://doi.org/10.1177/0149206310365901

Kennedy, J. P. (2015). Losing Control: A Test of Containment Theory and Ethical Decision Making. International Journal of Criminal Justice Sciences, 10(1).

Ketchen, D. J., Craighead, C. W., \& Buckley, M. R. (2008). Time bandits: How they are created, why they are tolerated, and what can be done about them. Business Horizons, 51(2), 141149. https://doi.org/https://doi.org/10.1016/j.bushor.2007.11.005

Khansa, L., Kuem, J., Siponen, M., \& Kim, S. S. (2017). To Cyberloaf or Not to Cyberloaf: The Impact of the Announcement of Formal Organizational Controls. Journal of Management Information Systems, 34(1), 141-176. https://doi.org/10.1080/07421222.2017.1297173

Kim, S. (2018). Managing Millennials' Personal Use of Technology at Work. Harvard Business Publishing.

Kim, K., del Carmen Triana, M., Chung, K., \& Oh, N. (2016). When Do Employees Cyberloaf? An Interactionist Perspective Examining Personality, Justice, and Empowerment. Human Resource Management, 55(6), 1041-1058. https://doi.org/10.1002/hrm.21699

Kim, S. J., \& Byrne, S. (2011). Conceptualizing personal web usage in work contexts: A preliminary framework. Computers in Human Behavior, 27(6), 2271-2283. https://doi.org/https://doi.org/10.1016/j.chb.2011.07.006

Koay, K. Y., Soh, P. C.-H., \& Chew, K. W. (2017a). Antecedents and consequences of cyberloafing: Evidence from the Malaysian ICT industry. First Monday; Volume 22, Number 3 - 6 March 2017DO - 10.5210/Fm.V22i3.7302 . Retrieved from https://firstmonday.org/ojs/index.php/fm/article/view/7302/5968

Koay, K. Y., Soh, P. C.-H., \& Chew, K. W. (2017b). Do employees' private demands lead to cyberloafing? The mediating role of job stress. Management Research Review, 40(9), 10251038. https://doi.org/10.1108/MRR-11-2016-0252

König, C. J., \& Caner de la Guardia, M. E. (2014). Exploring the positive side of personal internet use at work: Does it help in managing the border between work and nonwork? Computers in Human Behavior, 30, 355-360. https://doi.org/10.1016/j.chb.2013.09.021

Larose, R., Kim, J.-H., \& Peng, W. (2011). Social Networking: Addictive, Compulsive, Problematic or Just Another Media Habit? In A Networked Self: Identity, Community, and Culture on Social Network Sites (pp. 59-81).

Lawrence, T. B., \& Robinson, S. L. (2007). Ain't Misbehavin: Workplace Deviance as Organizational Resistance. Journal of Management, 33(3), 378-394. https://doi.org/10.1177/0149206307300816

Lee, D.-C., Lin, S.-H., Ma, H.-L., \& Wu, D.-B. (2017). Use of a Modified UTAUT Model to Investigate the Perspectives of Internet Access Device Users. International Journal of Human-Computer Interaction, 33(7), 549-564. https://doi.org/10.1080/10447318.2016.1261249

Levinson, H. (1970). A psychologist diagnoses merger failures. Harvard Business Review, 48(2), 139. 
Lewin, K. (1936). Pyschology of Success and Failure. Occupations: The Vocational Guidance Journal, 14(9), 926-930. https://doi.org/10.1002/j.2164-5892.1936.tb00275.x

Li, H., Zhang, J., \& Sarathy, R. (2010). Understanding compliance with internet use policy from the perspective of rational choice theory. Decision Support Systems, 48(4), 635-645. https://doi.org/10.1016/j.dss.2009.12.005

Li, H., Sarathy, R., Zhang, J., \& Luo, X. (2014). Exploring the effects of organizational justice, personal ethics and sanction on internet use policy compliance. Information Systems Journal, 24(6), 479-502. https://doi.org/10.1111/isj.12037

Liberman, B., Seidman, G., McKenna, K. Y. A., \& Buffardi, L. E. (2011). Employee job attitudes and organizational characteristics as predictors of cyberloafing. Computers in Human Behavior, 27(6), 2192-2199. https://doi.org/10.1016/j.chb.2011.06.015

Lim, V. K. G. (2002). The IT way of loafing on the job: cyberloafing, neutralizing and organizational justice. Journal of Organizational Behavior, 23(5), 675-694. https://doi.org/10.1002/job.161

Lim, V. K. G., \& Teo, T. S. H. (2005). Prevalence, perceived seriousness, justification and regulation of cyberloafing in Singapore: An exploratory study. Information $\mathcal{E}$ Management, 42(8), 1081-1093. https://doi.org/10.1016/j.im.2004.12.002

Lim, V. K. G., \& Chen, D. J. Q. (2012). Cyberloafing at the workplace: Gain or drain on work? Behaviour and Information Technology, 31(4), 343-353. https://doi.org/10.1080/01449290903353054

Liu, C., Yang, J., Liu, J., \& Zhu, L. (2018). The effect of abusive supervision on employee deviant behaviors: an identity-based perspective. The International Journal of Human Resource Management, 1-31. https://doi.org/10.1080/09585192.2018.1511613

Macey, W. H., \& Schneider, B. (2008). The meaning of employee engagement. Industrial and Organizational Psychology, 1(1), 3-30. https://doi.org/10.1111/j.1754-9434.2007.0002.x

Macher, K. (1988). Empowerment and the Bureaucracy. Training \& Development Journal, 42(9), 41.

Marasi, S., Bennett, R., \& Budden, H. (2018). The structure of an organization: Does it influence workplace deviance and its' dimensions? And to what extent? Journal of Managerial Issues, 30 .

Martin, L. E., Brock, M. E., Buckley, M. R., \& Ketchen Jr., D. J. (2010). Time banditry: Examining the purloining of time in organizations. Human Resource Management Review, 20(1), 2634. https://doi.org/10.1016/j.hrmr.2009.03.013

Maslach, C., Schaufeli, W. B., \& Leiter, M. P. (2001). Job Burnout. Annual Review of Psychology, 52(1), 397-422. https://doi.org/10.1146/annurev.psych.52.1.397

MacKenzie, S. B., \& Podsakoff, P. M. (2012). Common Method Bias in Marketing: Causes, Mechanisms, and Procedural Remedies. Journal of Retailing, 88(4), 542-555. https://doi.org/10.1016/j.jretai.2012.08.001

McAfee, A., Brynjolfsson, E., Davenport, T. H., Patil, D. J., \& Barton, D. (2012). Big data: the management revolution. Harvard Business Review, 90(10), 60-68. Retrieved from http://tarjomefa.com/wp-content/uploads/2017/04/6539-English-TarjomeFa-1.pdf 
McGuigan, L. (2005). The role of enabling bureaucracy and academic optimism in academic achievement growth. The Ohio State University.

Montagna, P. D. (1968). Professionalization and Bureaucratization in Large Professional Organizations. American Journal of Sociology, 74(2), 138-145. https://doi.org/10.1086/224616

Morton, N. A., \& Hu, Q. (2008). Implications of the fit between organizational structure and ERP: A structural contingency theory perspective. International Journal of Information Management, 28(5),

391-402. https://doi.org/https://doi.org/10.1016/j.ijinfomgt.2008.01.008

Mowday, R. T., Steers, R. M., \& Porter, L. W. (1979). The measurement of organizational commitment. Journal of Vocational Behavior, 14(2), 224-247. https://doi.org/10.1016/00018791(79)90072-1

Nevitt, J., \& Hancock, G. R. (2004). Evaluating Small Sample Approaches for Model Test Statistics in Structural Equation Modeling. Multivariate Behavioral Research, 39(3), 439478. https://doi.org/10.1207/S15327906MBR3903_3

Newman, D. A., \& Harrison, D. A. (2008). Been There, Bottled That: Are State and Behavioral Work Engagement New and Useful Construct "Wines"? Industrial and Organizational Psychology, 1(1), 31-35. https://doi.org/10.1111/j.1754-9434.2007.00003.x

Nicholson, P. J., \& Goh, S. C. (1983). The relationship of organization structure and interpersonal attitudes to role conflict and ambiguity in different work environments. Academy of Management Journal, 26(1), 148-155. https://doi.org/10.2307/256141

Nishii, L. H., Lepak, D. P., \& Schneider, B. (2008). Employee attributions of the "why" of HR practices: their effects on employee attitudes and behaviors, and customer satisfaction. Personnel Psychology, 61(3), 503-545. https://doi.org/10.1111/j.1744-6570.2008.00121.x

O'Neill, T. A., Hambley, L. A., \& Chatellier, G. S. (2014). Cyberslacking, engagement, and personality in distributed work environments. Computers in Human Behavior, 40, 152-160. https://doi.org/10.1016/j.chb.2014.08.005

Osborne, D., \& Plastrik, P. (1997). Banishing Bureaucracy: The Five Strategies for Reinventing Government. Addison-Wesley Publishing Company, Inc.

Pandey, J. (2018). Managing employee surplus: the cats, rats, camels and elephants of strategic downsizing matrix. Strategic HR Review. 17 (4), 220-223

Pandey, J. (2019). Factors affecting job performance: an integrative review of literature. Management Research Review. 42(2). 263-289

Pindek, S., Krajcevska, A., \& Spector, P. E. (2018). Cyberloafing as a coping mechanism: Dealing with workplace boredom. Computers in Human Behavior, 86, 147-152. https://doi.org/10.1016/j.chb.2018.04.040

Pines, A., \& Maslach, C. (1978). Characteristics of staff burnout in mental health settings. Hospital \& Community Psychiatry. US: American Psychiatric Assn.

Pratt, M. G. (1998). To be or not to be: Central questions in organizational identification. In Identity in organizations: Building theory through conversations. (pp. 171-207). Thousand Oaks, CA, US: Sage Publications, Inc. https://doi.org/10.4135/9781452231495.n6 
Priesemuth, M., Schminke, M., Ambrose, M. L., \& Folger, R. (2013). Abusive Supervision Climate: A Multiple-Mediation Model of its Impact on Group Outcomes. Academy of Management Journal, 57(5), 1513-1534. https://doi.org/10.5465/amj.2011.0237

Rammstedt, B., \& John, O. P. (2007). Measuring personality in one minute or less: A 10-item short version of the Big Five Inventory in English and German. Journal of Research in Personality, 41(1), 203-212. https://doi.org/10.1016/j.jrp.2006.02.001

Reckless, W. C. (1961). The Crime Problem (Ch. 18). New York: Appleton Century Crofts.

Reckless, W.C. (1967). The Crime Problem. New York: Appleton-Century-Crofts

Reckless, W., \& Dinitz, S. (1968). Pioneering with Self--Concept as a Vulnerability Factor in Delinquency. Journal of Criminal Law and Criminology, 58(4). Retrieved from https://scholarlycommons.law.northwestern.edu/jclc/vol58/iss4/6

Rich, B. L., Lepine, J. A., \& Crawford, E. R. (2010). Job Engagement: Antecedents and Effects on Job Performance. Academy of Management Journal, 53(3), 617-635. https://doi.org/10.5465/amj.2010.51468988

Richards, D. A., \& Schat, A. C. H. (2011). Attachment at (not to) work: Applying attachment theory to explain individual behavior in organizations. Journal of Applied Psychology, 96(1), 169-182. https://doi.org/10.1037/a0020372

Robinson, S. L., \& Bennett, R. J. (1995). A Typology of Deviant Workplace Behaviors: A Multidimensional Scaling Study. Academy of Management Journal, 38(2), 555-572. https://doi.org/10.5465/256693

Rousseau, D. M. (1978). Characteristics of departments, positions, and individuals: Contexts for attitudes and behavior. Administrative Science Quarterly, 23(4), 521-540. https://doi.org/10.2307/2392578

Salary.com. (2014). Wasting Time at Work Survey. Retrieved January 3, 2019, from https://www.salary.com/chronicles/2014-wasting-time-at-work/

Saparito, P. A., \& Coombs, J. E. (2013). Bureaucratic Systems' Facilitating and Hindering Influence on Social Capital. Entrepreneurship Theory and Practice, 37(3), 625-639. https://doi.org/10.1111/etap.12028

Schaufeli, W. B., \& Bakker, A. B. (2004). Job demands, job resources, and their relationship with burnout and engagement: a multi-sample study. Journal of Organizational Behavior, 25(3), 293-315. https://doi.org/10.1002/job.248

Schaufeli, W. B., Salanova, M., González-romá, V., \& Bakker, A. B. (2002). The Measurement of Engagement and Burnout: A Two Sample Confirmatory Factor Analytic Approach. Journal of Happiness Studies, 3(1), 71-92. https://doi.org/10.1023/A:1015630930326

Scheuermann, L. E., \& Langford, H. P. (1997). Perceptions of Internet Abuse, Liability, and Fair Use. Perceptual and Motor Skills, 85(3), 847-850. https://doi.org/10.2466/pms.1997.85.3.847

Schott, R. L. (2000). The origins of bureaucracy: an anthropological perspective. International Journal of Public Administration, 23(1), 53-78. https://doi.org/10.1080/01900690008525452

Seeman, M. (1971). The urban alienations: Some dubious theses from Marx to Marcuse. Journal of Personality and Social Psychology, 19(2), 135-143. https://doi.org/10.1037/h0031270 
Shantz, A., Alfes, K., Truss, C., \& Soane, E. (2013). The role of employee engagement in the relationship between job design and task performance, citizenship and deviant behaviours. The International Journal of Human Resource Management, 24(13), 2608-2627. https://doi.org/10.1080/09585192.2012.744334

Sheikh, A., Atashgah, M. S., \& Adibzadegan, M. (2015). The antecedents of cyberloafing: A case study in an Iranian copper industry. Computers in Human Behavior, 51(Pt A), 172179. https://doi.org/10.1016/j.chb.2015.04.042

Shepherd, M., Mejias, R., \& Klein, G. (2014). A Longitudinal Study to Determine Non-technical Deterrence Effects of Severity and Communication of Internet Use Policy for Reducing Employee Internet Abuse. In 2014 47th Hawaii International Conference on System Sciences (pp. 3159-3168). https://doi.org/10.1109/HICSS.2014.392

Shrivastava, A., Sharma, M. K., \& Marimuthu, P. (2016). Internet use at workplaces and its effects on working style in indian context: An exploration. Indian Journal of Occupational and Environmental Medicine, 20(2), 88-94. https://doi.org/10.4103/0019-5278.197531

Smith, D.(2013).Five principles for research ethics: Cover your bases with these ethical strategies. Monitor on Psychology, 34, 56. Retrieved from http://www.apa.org/monitor/jan03/principles.aspx

Smidts, A., Pruyn, A. T. H., \& van Riel, C. B. M. (2001). The impact of employee communication and perceived external prestige on organizational identification. Academy of Management Journal, 49(5), 1051-1062. Retrieved from http://www.jstor.org/stable/3069448

Soh, P. C.-H., Koay, K. Y., \& Lim, V. K. G. (2018). Understanding cyberloafing by students through the lens of an extended theory of planned behavior. First Monday; Volume 23, Number 6 - 4 June 2018. https://doi.org/10.5210/fm.v23i6.7837

Spector, P. E., Fox, S., Penney, L. M., Bruursema, K., Goh, A., \& Kessler, S. (2006). The dimensionality of counterproductivity: Are all counterproductive behaviors created equal? Journal of Vocational Behavior, 68(3), 446-460. https://doi.org/10.1016/j.jvb.2005.10.005

Stephens, K. K., \& Ford, J. L. (2015). Unintended consequences of a strategically ambiguous organizational policy selectively restricting mobile device use at work. Mobile Media $\mathcal{E}$ Communication, 4(2), 186-204. https://doi.org/10.1177/2050157915619211

Stuart, H. (1999). The effect of Organizational structure on corporate identity management. Corporate Reputation Review, 2(2), 151-164. https://doi.org/10.1057/palgrave.crr.1540075

Tajfel, H. (1982). Social Psychology of Intergroup Relations. Annual Review of Psychology, 33(1), 1-39. https://doi.org/10.1146/annurev.ps.33.020182.000245

Tepper, B. J., Duffy, M. K., \& Shaw, J. D. (2001). Personality moderators of the relationship between abusive supervision and subordinates' resistance. Journal of Applied Psychology, 86(5), 974-983. https://doi.org/10.1037/0021-9010.86.5.974

Ugrin, J. C., \& Michael Pearson, J. (2013). The effects of sanctions and stigmas on cyberloafing. Computers in Human Behavior, 29(3), 812-820. https://doi.org/10.1016/j.chb.2012.11.005 
Ugrin, J. C., Pearson, J. M., \& Nickle, S. M. (2018). An Examination of the Relationship between Culture and Cyberloafing Using the Hofstede Model. Journal of Internet Commerce, 17(1), 46-63. https://doi.org/10.1080/15332861.2018.1424395

Ugwu, F. O., \& Onyishi, I. E. (2017). Linking Perceived Organizational Frustration to Work Engagement: The Moderating Roles of Sense of Calling and Psychological Meaningfulness. Journal of Career Assessment, 26(2), 220-239. https://doi.org/10.1177/1069072717692735

Utaybi, S. M. (1992). Political development, bureaucracy and Saudi culture. Florida State University.

Van Doorn, O. N. (2011). Cyberloafing a multi-dimensional construct placed in a theoretical framework. Eindhoven University of Technology.

Van de Voorde, K., \& Beijer, S. E. (2015). The role of employee HR attributions in the relationship between high-performance work systems and employee outcomes. Human Resource Management Journal, 25(1), 62-78. https://doi.org/10.1111/1748-8583.12062

Van Dick, R., Ullrich, J., \& Tissington, P. A. (2006). Working Under a Black Cloud: How to Sustain Organizational Identification after a Merger*. British Journal of Management, 17(S1), S69-S79. https://doi.org/10.1111/j.1467-8551.2006.00479.x

Van Wyk, R., Boshoff, A. B., \& Cilliers, F. V. N. (2003). The prediction of job involvement for pharmacists and accountants. SA Journal of Industrial Psychology, 29(3), 61-67. https://doi.org/10.4102/sajip.v29i3.118

Van Wyk, S. M., de Beer, L. T., Pienaar, J., \& Schaufeli, W. B. (2016). The psychometric properties of a workplace boredom scale (DUBS) within the South African context. SA Journal of Industrial Psychology; Vol 42, No 1 (2016)DO - 10.4102/Sajip.V42i1.1326 . Retrieved from https://sajip.co.za/index.php/sajip/article/view/1326/1913

Vaast, E., \& Binz-Scharf, M. C. (2008). Bringing change in government organizations: evolution towards post-bureaucracy with web-based IT projects. ICIS 2008 Proceedings, 213.

Von Mises, L. (1944). The Treatment of "Irrationality" in the Social Sciences. Philosophy and Phenomenological Research, 4(4), 527-546. https://doi.org/10.2307/2103039

Wagner, D. T., Barnes, C. M., Lim, V. K. G., \& Ferris, D. L. (2012). Lost sleep and cyberloafing: Evidence from the laboratory and a daylight saving time quasi-experiment. Journal of Applied Psychology, 97(5), 1068-1076.https://doi.org/10.1037/a0027557

Wales, W. J., Patel, P. C., \& Lumpkin, G. T. (2013). In Pursuit of Greatness: CEO Narcissism, Entrepreneurial Orientation, and Firm Performance Variance. Journal of Management Studies, 50(6), 1041-1069. https://doi.org/10.1111/joms.12034

Weber, M. (1958). Essays in sociology. A Galaxy Book.

Werner, C., \& Schermelleh-Engel, K. (2010). Deciding between competing models: Chi-square difference tests. Goethe University. Available Online: Https://Perma. Cc/2RTR-8XPZ).

West, S. G., Taylor, A. B., \& Wu, W. (2012). Model fit and model selection in structural equation modeling. In Handbook of structural equation modeling. (pp. 209-231). New York, NY, US: Guilford Press. 
Yeik, K. K. (2018). Workplace ostracism and cyberloafing: a moderated-mediation model. Internet Research, 28(4), 1122-1141. https://doi.org/10.1108/IntR-07-2017-0268

Yellowlees, P. M., \& Marks, S. (2007). Problematic Internet use or Internet addiction? Computers in Human Behavior, 23(3), 1447-1453. https://doi.org/10.1016/j.chb.2005.05.004

Yoon, J., Baker, M. R., \& Ko, J.-W. (1994). Interpersonal Attachment and Organizational Commitment: Subgroup Hypothesis Revisited. Human Relations, 47(3), 329-351. https://doi.org/10.1177/001872679404700305

Zey-Ferrell, M., Weaver, K. M., \& Ferrell, O. C. (1979). Predicting Unethical Behavior Among Marketing Practitioners. Human Relations, 32(7), 557-569. https://doi.org/10.1177/001872677903200702

Zill-e-, H., Hussain, S., \& Thurasamy, R. (2017). Determinants of cyberloafing: a comparative study of a public and private sector organization. Internet Research, 27(1), 97-117. https://doi.org/10.1108/IntR-12-2014-0317

Zimmerman, J. (2001). The Effects Of Bureaucratization On Corruption, Deviant And Unethical Behavior In Organizations. Journal of Managerial Issues, 13(1), 119-128. Retrieved from http://www.jstor.org/stable/40604337

Zhao, H., Wayne, S. J., Glibkowski, B. C., \& Bravo, J. (2007). The impact of psychological contract breach on work-related outcomes: a meta-analysis. Personnel Psychology, 60(3), 647-680. https://doi.org/10.1111/j.1744-6570.2007.00087.x

Zoghbi Manrique de Lara, P. (2006). Fear in organizations. Journal of Managerial Psychology, 21(6), 580-592. https://doi.org/10.1108/02683940610684418

Zoghbi Manrique de Lara, P. (2009). Inequity, conflict, and compliance dilemma as causes of cyberloafing. International Journal of Conflict Management, 20(2), 188-201. https://doi.org/10.1108/10444060910949630

Zoghbi Manrique de Lara, P., Verano Tacoronte, D. and Ting Ding, J. (2006), "Do current anticyberloafing disciplinary practices have a replica in research findings?", Internet Research, Vol. 16 No. 4, pp. 450-467. https://doi.org/10.1108/10662240610690052

Zoghbi-Manrique-de-Lara, P., \& Viera-Armas, M. (2017). Corporate Culture as a Mediator in the Relationship Between Ethical Leadership and Personal Internet Use. Journal of Leadership $\mathcal{E} \quad$ Organizational Studies, 24(3), 357-371. https://doi.org/10.1177/1548051817696877 


\section{Annexure I}

\section{Systematic Literature Review}

\begin{tabular}{|c|c|c|c|c|c|c|}
\hline S.No. & Authors & Antecedents & $\begin{array}{l}\text { Context/whic } \\
\mathrm{h} \text { industry }\end{array}$ & $\begin{array}{l}\text { Sample } \\
\text { characteristics }\end{array}$ & $\begin{array}{l}\text { Analytical } \\
\text { strategy }\end{array}$ & Theory \\
\hline 1 & $\begin{array}{l}\text { (Aghaz \& Sheikh, } \\
\text { 2016) }\end{array}$ & $\begin{array}{l}\text { Job burnout - emotional } \\
\text { exhaustion, decreased personal } \\
\text { efficacy and cynicism }\end{array}$ & $\begin{array}{l}\text { Organizationa } \\
1 \text { context }\end{array}$ & 298 employees & $\begin{array}{l}\text { Pearson } \\
\text { correlation } \\
\text { coefficients } \\
\text { Confirmatory } \\
\text { factor analysis }\end{array}$ & NA \\
\hline 2 & $\begin{array}{l}\text { (Arciniega, Stanley, } \\
\text { Puga-Méndez, } \\
\text { Obregón-Schael, \& } \\
\text { Politi-Salame, 2017) }\end{array}$ & Self-enhancement & $\begin{array}{l}\text { Organizationa } \\
1 \text { context }\end{array}$ & 145 employees & $\begin{array}{l}\text { Hierarchical } \\
\text { logistic regression }\end{array}$ & $\begin{array}{l}\text { Schwartz's } \\
\text { theory of } \\
\text { individual } \\
\text { values }\end{array}$ \\
\hline 3 & (Askew et al., 2014) & $\begin{array}{l}\text { Descriptive norms, cyberloafing } \\
\text { attitudes, ability to hide } \\
\text { cyberloafing, intentions }\end{array}$ & $\begin{array}{l}\text { Organizationa } \\
1 \text { context }\end{array}$ & 429 employees & Regression & $\begin{array}{l}\text { Theory of } \\
\text { Planned } \\
\text { behavior }\end{array}$ \\
\hline 4 & $\begin{array}{l}\text { (Baturay \& Toker, } \\
\text { 2015) }\end{array}$ & $\begin{array}{l}\text { Demographic variables - gender, } \\
\text { grade, Internet skills, Internet } \\
\text { usage and Internet experience }\end{array}$ & $\begin{array}{l}\text { University } \\
\text { context }\end{array}$ & $\begin{array}{l}282 \text { student } \\
\text { respondents }\end{array}$ & $\begin{array}{l}\text { Descriptive } \\
\text { statistics } \\
\text { Multiple linear } \\
\text { regression } \\
\text { analysis } \\
\text { Structural } \\
\text { Equation } \\
\text { Modeling } \\
\end{array}$ & NA \\
\hline 5 & $\begin{array}{l}\text { (Blanchard \& Henle, } \\
\text { 2008) }\end{array}$ & $\begin{array}{l}\text { Employees' perceptions of co- } \\
\text { worker and supervisor norms } \\
\text { supporting cyberloafing, external } \\
\text { locus of control }\end{array}$ & $\begin{array}{l}\text { Organizationa } \\
1 \text { context }\end{array}$ & $\begin{array}{l}202 \text { executive } \\
\text { MBA students }\end{array}$ & $\begin{array}{l}\text { Hierarchical } \\
\text { regression }\end{array}$ & NA \\
\hline
\end{tabular}




\begin{tabular}{|c|c|c|c|c|c|c|}
\hline 6 & $\begin{array}{l}\text { (Cheng, Zhou, Guo, \& } \\
\text { Yang, 2018) }\end{array}$ & $\begin{array}{l}\text { Perceived overqualification, } \\
\text { need for achievement, } \\
\text { harmonious passion }\end{array}$ & $\begin{array}{l}\text { Organizationa } \\
1 \text { context }\end{array}$ & $\begin{array}{l}456 \text { in first wave, } \\
382 \text { in second } \\
\text { wave }\end{array}$ & $\begin{array}{l}\text { Structural } \\
\text { Equation } \\
\text { Modelling }\end{array}$ & Equity Theory \\
\hline 7 & (Güğerçin, 2019) & $\begin{array}{l}\text { Techno-stress (Techno-overload, } \\
\text { Techno-complexity, Techno- } \\
\text { invasion) }\end{array}$ & $\begin{array}{l}\text { Organizationa } \\
1 \text { context }\end{array}$ & $\begin{array}{l}252 \text { white-collar } \\
\text { employees }\end{array}$ & $\begin{array}{l}\text { Regression } \\
\text { analysis }\end{array}$ & $\begin{array}{l}\text { Neutralisation } \\
\text { theory }\end{array}$ \\
\hline 8 & $\begin{array}{l}\text { (Henle \& Blanchard, } \\
\text { 2008) }\end{array}$ & $\begin{array}{l}\text { Role ambiguity, role conflict, } \\
\text { role overload, perceived } \\
\text { organizational sanctions }\end{array}$ & $\begin{array}{l}\text { Organizationa } \\
1 \text { context }\end{array}$ & $\begin{array}{l}194 \text { executive } \\
\text { MBA students }\end{array}$ & $\begin{array}{l}\text { Hierarchical } \\
\text { Regression } \\
\text { Analysis }\end{array}$ & Role theory \\
\hline 9 & $\begin{array}{l}\text { (Huma, Hussain, } \\
\text { Thurasamy, \& Malik, } \\
\text { 2017) }\end{array}$ & $\begin{array}{l}\text { Affect, social factor, perceived } \\
\text { consequences, habit, facilitating } \\
\text { condition, intention }\end{array}$ & $\begin{array}{l}\text { Organizationa } \\
1 \text { context }\end{array}$ & $\begin{array}{l}85 \text { responses } \\
\text { from a public } \\
\text { airline and } 85 \\
\text { responses from a } \\
\text { private sector } \\
\text { airline. }\end{array}$ & SEM & $\begin{array}{l}\text { Theory of } \\
\text { interpersonal } \\
\text { behavior } \\
\text { (TIB). }\end{array}$ \\
\hline 10 & $\begin{array}{l}\text { (Jia, Jia, \& Karau, } \\
\text { 2013) }\end{array}$ & $\begin{array}{l}\text { Big Five personality factors } \\
\text { (Conscientiousness, emotional } \\
\text { stability, extroversion, openness } \\
\text { to experience), presence of an } \\
\text { Internet usage policy, perceived } \\
\text { work meaningfulness }\end{array}$ & $\begin{array}{l}\text { Organizationa } \\
1 \text { context }\end{array}$ & 147 employees & $\begin{array}{l}\text { Hierarchal } \\
\text { regression }\end{array}$ & $\begin{array}{l}\text { General } \\
\text { Deterrence } \\
\text { Theory }\end{array}$ \\
\hline 11 & $\begin{array}{l}\text { (Khansa, Kuem, } \\
\text { Siponen, \& Kim, 2017) }\end{array}$ & $\begin{array}{l}\text { Neutralization, perceived risk, } \\
\text { past cyberloafing, peer } \\
\text { cyberloafing }\end{array}$ & $\begin{array}{l}\text { Organizationa } \\
1 \text { context/ }\end{array}$ & 451 employees & $\begin{array}{l}\text { Structural } \\
\text { Equation } \\
\text { Modeling (SEM) }\end{array}$ & $\begin{array}{l}\text { Akers's Social } \\
\text { Learning } \\
\text { Theory }\end{array}$ \\
\hline 12 & $\begin{array}{l}\text { (Kim, del Carmen } \\
\text { Triana, Chung, \& Oh, } \\
\text { 2016) }\end{array}$ & $\begin{array}{l}\text { Conscientiousness, emotional } \\
\text { stability, } \\
\text { organizational justice }\end{array}$ & $\begin{array}{l}\text { Organizationa } \\
1 \text { context }\end{array}$ & 247 employees & $\begin{array}{l}\text { CFA, hierarchical } \\
\text { linear regression. }\end{array}$ & $\begin{array}{l}\text { Trait } \\
\text { activation } \\
\text { theory, } \\
\text { Organizationa } \\
\text { l justice }\end{array}$ \\
\hline
\end{tabular}




\begin{tabular}{|c|c|c|c|c|c|c|}
\hline 13 & (Yeik, 2018) & $\begin{array}{l}\text { Workplace ostracism, emotional } \\
\text { exhaustion }\end{array}$ & $\begin{array}{l}\text { Organizationa } \\
1 \text { context }\end{array}$ & 179 employees & SEM & $\begin{array}{l}\text { Conservation } \\
\text { of resources } \\
\text { theory }\end{array}$ \\
\hline 14 & $\begin{array}{l}\text { (Koay, Soh, \& Chew, } \\
\text { 2017a) }\end{array}$ & $\begin{array}{l}\text { Intention, perceived } \\
\text { consequence, affect } \\
\text { social factors, facilitating } \\
\text { conditions, habit }\end{array}$ & $\begin{array}{l}\text { Organizationa } \\
1 \text { context }\end{array}$ & 301 employees & $\begin{array}{l}\text { Variance-based } \\
\text { structural } \\
\text { equation } \\
\text { modelling }\end{array}$ & $\begin{array}{l}\text { Theory of } \\
\text { interpersonal } \\
\text { behavior }\end{array}$ \\
\hline 15 & (Koay et al., 2017b) & Private demands, jobs stress & $\begin{array}{l}\text { Organizationa } \\
1 \text { context }\end{array}$ & 301 employees & SEM & $\begin{array}{l}\text { Border theory, } \\
\text { conservation } \\
\text { of resources } \\
\text { theory and } \\
\text { general strain } \\
\text { theory }\end{array}$ \\
\hline 16 & $\begin{array}{l}\text { (König \& Caner de la } \\
\text { Guardia, 2014) }\end{array}$ & $\begin{array}{l}\text { Private demands, job } \\
\text { identification }\end{array}$ & $\begin{array}{l}\text { Organizationa } \\
1 \text { context }\end{array}$ & 190 employees & $\begin{array}{l}\text { Hierarchical } \\
\text { multiple } \\
\text { regression }\end{array}$ & $\begin{array}{l}\text { Work/family } \\
\text { border theory }\end{array}$ \\
\hline 17 & $\begin{array}{l}\text { (Lee, Lin, Ma, \& Wu, } \\
\text { 2017) }\end{array}$ & $\begin{array}{l}\text { Perceived enjoyment, } \\
\text { performance expectancy, effort } \\
\text { expectancy, social influence, } \\
\text { age, gender, educational level }\end{array}$ & $\begin{array}{l}\text { Organizationa } \\
1 \text { context }\end{array}$ & 503 employees & $\begin{array}{l}\text { Regression } \\
\text { Johnson-Neyman } \\
\text { to verify the } \\
\text { moderate effects }\end{array}$ & UTAUT \\
\hline 18 & (Liberman et al., 2011) & $\begin{array}{l}\text { Job attitudes (job involvement } \\
\text { and intrinsic involvement), } \\
\text { organizational characteristics } \\
\text { (perceived cyberloafing of one's } \\
\text { co-workers managerial support } \\
\text { for internet usage), attitudes } \\
\text { towards cyberloafing, other non- } \\
\text { Internet loafing behaviors }\end{array}$ & $\begin{array}{l}\text { Organizationa } \\
1 \text { context }\end{array}$ & 143 employees & Regression & $\mathrm{NA}$ \\
\hline 19 & $(\mathrm{Lim}, 2002)$ & $\begin{array}{l}\text { Organizational Justice } \\
\text { (Distributive, Procedural and } \\
\text { Interactional), metaphor of the } \\
\text { Ledger }\end{array}$ & $\begin{array}{l}\text { Organizationa } \\
1 \text { context }\end{array}$ & 188 employees & $\begin{array}{l}\text { Structural } \\
\text { Equation } \\
\text { Modeling, } \\
\text { Interview }\end{array}$ & $\begin{array}{l}\text { Social } \\
\text { exchange } \\
\text { theory, } \\
\text { Organizationa }\end{array}$ \\
\hline
\end{tabular}




\begin{tabular}{|c|c|c|c|c|c|c|}
\hline & & & & & & $\begin{array}{l}1 \text { justice, } \\
\text { Neutralization } \\
\text { theory }\end{array}$ \\
\hline 20 & $\begin{array}{l}\text { (O’Neill, Hambley, \& } \\
\text { Chatellier, 2014) }\end{array}$ & $\begin{array}{l}\text { Agreeableness, neuroticism, } \\
\text { openness to experience, } \\
\text { conscientiousness }\end{array}$ & $\begin{array}{l}\text { Organizationa } \\
1 \text { context }\end{array}$ & 148 employees & $\begin{array}{l}\text { Hierarchal } \\
\text { regression } \\
\text { Relative } \\
\text { importance } \\
\text { analysis (RIA) }\end{array}$ & $\begin{array}{l}\text { Person-job fit } \\
\text { Trait } \\
\text { activation } \\
\text { theory }\end{array}$ \\
\hline 21 & (Pindek et al., 2018) & $\begin{array}{l}\text { Boredom at work, work } \\
\text { underload }\end{array}$ & $\begin{array}{l}\text { University } \\
\text { context }\end{array}$ & $\begin{array}{l}463 \text { non-teaching } \\
\text { staff }\end{array}$ & $\begin{array}{l}\text { Maximum } \\
\text { Likelihood } \\
\text { Estimation } \\
(\text { MLR) }\end{array}$ & $\mathrm{NA}$ \\
\hline 22 & $\begin{array}{l}\text { (Sheikh, Atashgah, \& } \\
\text { Adibzadegan, 2015) }\end{array}$ & $\begin{array}{l}\text { Ability to hide cyberloafing, } \\
\text { subjective norms, behavioural } \\
\text { attitude, attitudes \& intentions } \\
\text { toward cyberloafing }\end{array}$ & $\begin{array}{l}\text { University } \\
\text { context }\end{array}$ & 195 employees & $\begin{array}{l}\text { Linear regression } \\
\text { analysis }\end{array}$ & $\begin{array}{l}\text { Theory of } \\
\text { Planned } \\
\text { Behaviour } \\
\text { (TPB) }\end{array}$ \\
\hline 23 & $\begin{array}{l}\text { (Soh, Koay, \& Lim, } \\
\text { 2018) }\end{array}$ & $\begin{array}{l}\text { Class engagement, habit, } \\
\text { attitude, prescriptive norms, } \\
\text { perceived behavioural control }\end{array}$ & $\begin{array}{l}\text { University } \\
\text { context }\end{array}$ & $\begin{array}{l}238 \text { university } \\
\text { students }\end{array}$ & $\begin{array}{l}\text { Consistent Partial } \\
\text { Least Squares } \\
\text { (PLS) }\end{array}$ & $\begin{array}{l}\text { Theory of } \\
\text { planned } \\
\text { behavior } \\
\text { (TPB) }\end{array}$ \\
\hline 24 & $\begin{array}{l}\text { (Ugrin \& Michael } \\
\text { Pearson, 2013) }\end{array}$ & $\begin{array}{l}\text { Sanction, detection, } \\
\text { enforcement, perceived } \\
\text { abusiveness }\end{array}$ & $\begin{array}{l}\text { Organizationa } \\
1 \text { context }\end{array}$ & $\begin{array}{l}69 \text { business } \\
\text { students, } 81 \\
\text { employees }\end{array}$ & $\begin{array}{l}\text { Experimental } \\
\text { survey } \\
\text { ANNOVA } \\
\end{array}$ & $\begin{array}{l}\text { General } \\
\text { Deterrence } \\
\text { Theory (GDT) }\end{array}$ \\
\hline 25 & (Ugrin et al., 2018) & $\begin{array}{l}\text { Power distance, masculinity } \\
\text { versus femininity, uncertainty } \\
\text { avoidance, long-term versus } \\
\text { short-term orientation, } \\
\text { indulgence versus restraint }\end{array}$ & $\begin{array}{l}\text { Organizationa } \\
1 \text { context }\end{array}$ & $\begin{array}{l}249 \text { Executive } \\
\text { MBA and MBA } \\
\text { students from } 17 \\
\text { countries }\end{array}$ & Regression & NA \\
\hline 26 & $\begin{array}{l}\text { (Wagner, Barnes, Lim, } \\
\& \text { Ferris, 2012) }\end{array}$ & $\begin{array}{l}\text { Sleep quality, day light saving } \\
\text { time (DST), conscientiousness }\end{array}$ & $\begin{array}{l}\text { University } \\
\text { context }\end{array}$ & 96 Students & $\begin{array}{l}\text { Hierarchical } \\
\text { Linear Modeling } \\
\text { (HLM) }\end{array}$ & $\begin{array}{l}\text { Ego depletion } \\
\text { model of self- } \\
\text { regulation }\end{array}$ \\
\hline
\end{tabular}




\begin{tabular}{|c|c|c|c|c|c|c|}
\hline 27 & $\begin{array}{l}\text { Zoghbi Manrique de } \\
\text { Lara, 2006) }\end{array}$ & $\begin{array}{l}\text { Interactional justice, fear of } \\
\text { formal punishment }\end{array}$ & $\begin{array}{l}\text { University } \\
\text { context }\end{array}$ & $\begin{array}{l}147 \text { non-teaching } \\
\text { staff }\end{array}$ & $\begin{array}{l}\text { Structural } \\
\text { Equation } \\
\text { Modeling }\end{array}$ & NA \\
\hline 28 & $\begin{array}{l}\text { (Zoghbi Manrique de } \\
\text { Lara, Tacoronte, \& } \\
\text { Ding, 2006) }\end{array}$ & $\begin{array}{l}\text { Physical leadership proximity, } \\
\text { perceived organizational control, } \\
\text { fear of formal punishment }\end{array}$ & $\begin{array}{l}\text { University } \\
\text { context }\end{array}$ & $\begin{array}{l}147 \text { non- } \\
\text { teaching staff }\end{array}$ & $\begin{array}{l}\text { Structural } \\
\text { Equation } \\
\text { Modeling }\end{array}$ & $\begin{array}{l}\text { Social } \\
\text { exchange } \\
\text { theory, } \\
\text { Control theory }\end{array}$ \\
\hline 29 & $\begin{array}{l}\text { (Zoghbi Manrique de } \\
\text { Lara, 2009) }\end{array}$ & $\begin{array}{l}\text { Procedural justice, perceptions } \\
\text { of normative conflict }\end{array}$ & $\begin{array}{l}\text { University } \\
\text { context }\end{array}$ & $\begin{array}{l}147 \text { non- } \\
\text { teaching staff }\end{array}$ & $\begin{array}{l}\text { Structural } \\
\text { Equation } \\
\text { Modeling } \\
\end{array}$ & NA \\
\hline 30 & $\begin{array}{l}\text { (Zoghbi Manrique de } \\
\text { Lara \& Viera-Armas, } \\
\text { 2017) }\end{array}$ & $\begin{array}{l}\text { Ethical leadership, corporate } \\
\text { culture [clan culture, market } \\
\text { culture, and hierarchal culture] }\end{array}$ & $\begin{array}{l}\text { Organizationa } \\
1 \text { context }\end{array}$ & 300 employees & $\begin{array}{l}\text { Structural } \\
\text { Equation } \\
\text { Modelling }\end{array}$ & \begin{tabular}{|l} 
Social \\
learning \\
theory
\end{tabular} \\
\hline
\end{tabular}


Annexure II

Classification of antecedents

\begin{tabular}{|c|c|c|c|c|c|c|c|c|c|}
\hline Perception & State & Behaviour & Attitude & Personality & Environment & Skill & Emotion & Demographics & Others \\
\hline $\begin{array}{l}\text { Neutralization, perceived risk, } \\
\text { peer cyberloafing, } \\
\text { organizational justice } \\
\text { (procedural justice, } \\
\text { interactional justice, } \\
\text { distributive justice), } \\
\text { perception of normative } \\
\text { conflict, physical leadership } \\
\text { proximity, metaphor of the } \\
\text { ledger, perceived work } \\
\text { meaningfulness, perceived } \\
\text { consequences, social factors, } \\
\text { ethical leadership, corporate } \\
\text { culture (clan culture, market } \\
\text { culture, and hierarchal } \\
\text { culture), employees' } \\
\text { perceptions of co-worker, } \\
\text { supervisor norms supporting } \\
\text { cyberloafing, work underload, } \\
\text { organizational characteristics } \\
\text { (perceived cyberloafing of } \\
\text { one's co-workers, managerial } \\
\text { support for internet usage), } \\
\text { descriptive norms, subjective } \\
\text { norms, prescriptive norms, } \\
\text { sanction, detection, } \\
\text { enforcement, perceived } \\
\text { abusiveness, role } \\
\text { ambiguity, role conflict, role } \\
\text { overload, class } \\
\text { engagement, perceived } \\
\text { behavioural control, } \\
\text { workplace } \\
\text { ostracism, perceived } \\
\text { enjoyment. }\end{array}$ & $\begin{array}{l}\text { Power } \\
\text { distance, } \\
\text { masculinity } \\
\text { versus } \\
\text { femininity, } \\
\text { uncertainty } \\
\text { avoidance, } \\
\text { long-term } \\
\text { versus short- } \\
\text { term } \\
\text { orientation, } \\
\text { indulgence } \\
\text { versus } \\
\text { restraint, job } \\
\text { burnout, } \\
\text { boredom at } \\
\text { work, job } \\
\text { stress, } \\
\text { emotional } \\
\text { exhaustion, } \\
\text { technostress. }\end{array}$ & $\begin{array}{l}\text { Past- } \\
\text { cyberloafing, } \\
\text { internet } \\
\text { usage, } \\
\text { internet } \\
\text { experience, } \\
\text { habit, other } \\
\text { non-internet } \\
\text { loafing } \\
\text { behaviors, } \\
\text { performance } \\
\text { expectancy, } \\
\text { effort } \\
\text { expectancy. }\end{array}$ & $\begin{array}{l}\text { Job attitude } \\
\text { (job } \\
\text { involvement } \\
\text { and intrinsic } \\
\text { involvement), } \\
\text { cyberloafing } \\
\text { attitudes, job } \\
\text { identification, } \\
\text { behavioural } \\
\text { attitude. }\end{array}$ & $\begin{array}{l}\text { Big five } \\
\text { personality, } \\
\text { external locus of } \\
\text { control, } \\
\text { procrastination, } \\
\text { honesty, general } \\
\text { self-efficacy. }\end{array}$ & $\begin{array}{l}\text { Presence of an } \\
\text { internet usage } \\
\text { policy, } \\
\text { facilitating } \\
\text { conditions, } \\
\text { day light } \\
\text { saving time. }\end{array}$ & $\begin{array}{l}\text { Internet } \\
\text { skills, } \\
\text { ability to } \\
\text { hide } \\
\text { cyberloafin } \\
\text { g, self- } \\
\text { regulation. }\end{array}$ & $\begin{array}{l}\text { Fear of } \\
\text { formal } \\
\text { punishment, } \\
\text { affect, } \\
\text { harmonious } \\
\text { passion. }\end{array}$ & $\begin{array}{l}\text { Gender, grade, } \\
\text { age, } \\
\text { educational } \\
\text { level }\end{array}$ & $\begin{array}{l}\text { Intention, } \\
\text { private } \\
\text { demands, } \\
\text { sleep quality, } \\
\text { need for } \\
\text { achievement, } \\
\text { self } \\
\text { enhancement }\end{array}$ \\
\hline
\end{tabular}


Copyright: (C) 2020 Soral, Arayankalam \& Pandey. This is an open-access article distributed under the terms of the Creative Commons Attribution-NonCommercial 3.0 Australia License, which permits non-commercial use, distribution, and reproduction in any medium, provided the original author and AJIS are credited.

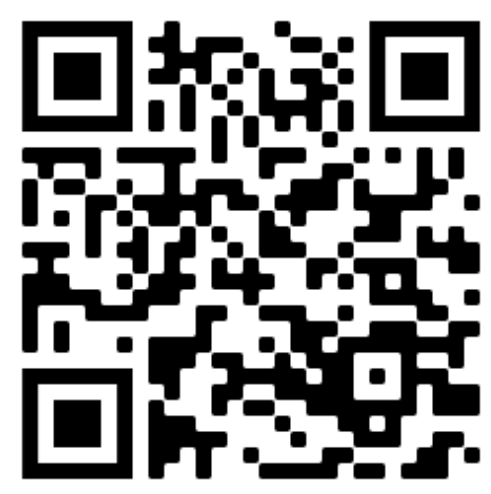

